\title{
Information asymmetry, valuation, and the corporate spin-off decision ${ }^{\text {is }}$
}

\author{
Sudha Krishnaswamia,*, Venkat Subramaniam ${ }^{\mathrm{b}}$ \\ ${ }^{a}$ College of Business Administration, University of New Orleans, New Orleans, LA 70148, USA \\ ${ }^{\mathrm{b}}$ A.B. Freeman School of Business, Tulane University, New Orleans, LA 70118, USA
}

Received 12 August 1997; received in revised form 15 July 1998; accepted 1 January 1999

\begin{abstract}
We empirically analyze the information hypothesis that the separation of a firm's divisions into independently traded units through a spin-off enhances value because it mitigates information asymmetry about the firm. Consistent with this hypothesis, we find that firms that engage in spin-offs have higher levels of information asymmetry compared to their industry and size matched counterparts and the information problems decrease significantly after the spin-off. The gains around spin-offs are positively related to the degree of information asymmetry, and this relation is more pronounced for firms with fewer negative synergies between divisions. Finally, firms with higher growth opportunities and firms in need of external capital show a higher propensity to engage in spin-offs. They also raise more capital following a spin-off, which is consistent with the view that

\footnotetext{
*Corresponding author. Tel.: + 1-504-280-6488; fax: + 1-504-280-6397.
}

E-mail address: skrishn1@uno.edu (S. Krishnaswami)

${ }^{7}$ We thank Jeffrey Allen, John Bizjak, Peter Brous, Rick Carter, Arnold Cowan, Dave Denis, Dave Ellis, Don Fraser, Steven Pottier, Russ Robins, Atulya Sarin, Ajai Singh, and seminar participants at Iowa State University, Santa Clara University, Seattle University, Temple University, Texas A\&M University, the University of New Orleans, the 1996 Western Finance Association meetings and the 1998 Financial Management Association meetings for their comments on an earlier version of the paper. We thank Srini Krishnamurthy for providing us some of the equity issues data. We also thank $\mathrm{I} / \mathrm{B} / \mathrm{E} / \mathrm{S}$ International, Inc., for providing us earnings forecast data as part of an academic program to encourage earnings expectations research. We are especially grateful to Scott Lee, an anonymous referee, and G. William Schwert (the editor) for suggestions that have improved the paper substantially. All errors remain our responsibility.
\end{abstract}


these firms mitigate information asymmetry before approaching the capital market for funds. (C) 1999 Elsevier Science S.A. All rights reserved.

JEL classification: G34; D82

Keywords: Spin-offs; Divestitures; Information asymmetry

\section{Introduction}

Over the last decade, mergers, acquisitions, and other forms of expansion in operations have declined sharply, and many conglomerates have resorted to downsizing and focusing their businesses to their core competencies. ${ }^{1} \mathrm{~A}$ corporate spin-off is one of several ways in which a firm may divest a division and improve its focus. A spin-off is a pro-rata distribution of the shares of a firm's subsidiary to the shareholders of the firm. There is neither a dilution of equity nor a transfer of ownership from the current shareholders. After the distribution, the operations and management of the subsidiary are separated from those of the parent. Spin-offs constitute a unique mode of divesting assets since they involve no cash transactions. Thus, they cannot be motivated by a desire to generate cash to pay off debt, as is often the case with other modes of divestitures.

Extant literature documents a positive stock price reaction around announcements of spin-offs. These abnormal returns are in the order of $2.4-4.3 \%$ as shown in different time periods and in different studies (see Hite and Owers, 1983; Miles and Rosenfeld, 1983; Schipper and Smith, 1983; Rosenfeld, 1984). More recently, Cusatis et al. (1993) show that even the long-term performance of firms involved in spin-offs is abnormally positive. Academic researchers have provided various reasons to explain these gains. Foremost among the reasons are improvement in focus and the elimination of negative synergies, transfer of wealth from bondholders to shareholders, tax and regulatory advantages, and recontracting benefits after the spin-off.

Practitioners and the popular press, on the other hand, usually propose an information-related motivation for spin-offs. For instance, CEOs of most firms involved in spin-offs claim that the spin-off improves the firm's market value because investors are able to perceive value more clearly after the spin-off. They argue that as separate entities the consequence of a temporary decline in the performance of one entity does not spill over and adversely affect the other. For example, Robert Allen, the chairman of AT\&T, while discussing the motivation behind their recent spin-off decision claimed that "the market value of

\footnotetext{
${ }^{1}$ This phenomenon is documented in Hoskisson and Hitt (1994), Comment and Jarrell (1995), and John and Ofek (1995) among others.
} 
AT\&T was being buried. Investors couldn't understand the strategy of the combined firm". After the spin-off AT\&T would be the biggest pure play in telecommunications. "Investors will clearly understand it now" (quoted in Keller, 1995). ${ }^{2}$

If the elimination of negative synergies, improvements in focus, or tax and regulatory considerations are the only motives behind the separation of a parent from its subsidiary then any other type of divestiture should work just as well as a spin-off. These motives explain divestitures in general, but do not offer specific insights into the comparative advantage of divesting through a spin-off. Spinoffs differ from other modes of divestitures such as asset sales and equity carve-outs because there is no cash inflow to the firm. If the firm is currently undervalued, as the CEOs and practitioners contend, then a spin-off is an especially appropriate mode of separation because undervaluation does not affect the cash inflows to the firm since the subsidiary is not being sold. If the separation of an undervalued firm into individually operated units, with separately traded shares, improves the accuracy of information processing about the individual divisions of the firm, then the sum of the separated parts may be greater than the market value of the combined firm. Such an improvement in market valuation will arise if the divisions are better able to convey information about their individual operating efficiency and future prospects when they are separate entities than when they are a combined unit.

In this paper we empirically analyze the information hypothesis that a spin-off enhances value because it mitigates the information asymmetry in the market about the profitability and operating efficiency of the different divisions of the firm. Consistent with the premise of the information hypothesis we find that firms that engage in spin-offs have higher levels of information asymmetry about their value than their industry- and size-matched counterparts. In particular, for firms that engage in spin-offs, the analysts' earnings forecast errors, the dispersion in analysts' forecasts, and three other measures of information asymmetry are significantly higher than those of their control firms. We also find that for firms that engage in spin-offs all five measures of information asymmetry decrease substantially after the completion of the spin-off, which is consistent with the view that a spin-off mitigates information problems.

Using conditional logistic regressions we find that firms with higher levels of information asymmetry and those that are more diversified have a higher likelihood of engaging in spin-offs than other firms. Firms with higher growth opportunities and those with less internally generated capital also show a higher propensity to engage in spin-offs, although spin-offs themselves generate no new

${ }^{2}$ The following quotations from the Wall Street Journal about two other recent spin-off proposals also emphasize the information-related reasoning: "independently traded shares of the engineering unit would produce a higher overall valuation for Raytheon" (Dennis J. Picard, CEO of Raytheon, quoted in Carton, 1995), and "Wall Street was undervaluing the food unit and would give it a juicy premium as a stand alone unit" (Hwang, 1995). 
capital for the firms. This result, combined with our finding that the frequency of equity issues and the total amount of capital raised increase significantly in the two years following a spin-off, suggests that firms mitigate their information problems through a spin-off before approaching the external capital markets to raise funds.

The regression results indicate that the gains from a spin-off are larger for firms with higher levels of information asymmetry about their value. This result obtains even after controlling for the level of negative synergies between divisions, another factor that may motivate a spin-off. For firms that spin off related subsidiaries, i.e., firms that should have fewer negative synergies, information asymmetry is a more important explanation of the gains from a spin-off. This is consistent with the theory that, while negative synergies may play a role in explaining spin-off gains, mitigation of information problems is also an important factor.

The rest of the paper is organized as follows. Section 2 presents a review of the literature and develops the main hypotheses. Section 3 describes the sample selection procedure, the sample characteristics, and the measures of information asymmetry used in this study. Section 4 discusses the results of the univariate and regression analyses. Section 5 provides some concluding comments.

\section{Information asymmetry and the spin-off decision}

Several studies have empirically analyzed the sources of shareholder gains around spin-offs (see Hite and Owers, 1983; Miles and Rosenfeld, 1983; Schipper and Smith, 1983; Cusatis et al., 1993; Seward and Walsh, 1996; Daley et al., 1997; Desai and Jain, 1999). The potential sources of gains from spin-offs analyzed in these studies may be classified as follows: (i) transfer of wealth from bondholders to shareholders, (ii) tax and regulatory advantages, (iii) restructuring of incentive contracts, and (iv) improved focus and elimination of negative synergies. Among these explanations, the improved focus and elimination of negative synergies hypothesis has received broad empirical support.

The transfer of wealth hypothesis argues that during a spin-off the assets and liabilities are restructured in a manner that involves a transfer of wealth from the bondholders and other stakeholders to the shareholders of the firm. A recent example of wealth transfer through a spin-off is in Parrino (1997). In a case study of the Marriott spin-off he shows that the restructuring not only reduced the collateral on Marriott's existing debt, but also reduced the bondholder claims on cash flows from the business. This resulted in a large increase in the stock price and an associated decrease in the value of the firm's debt. Hite and Owers (1983) and Schipper and Smith (1983), however, find little evidence of wealth transfers on average in a large sample of spin-offs. Both studies find that the announcement period bond returns are not significantly different from zero. 
Schipper and Smith find that there is a decline in bond ratings after the spin-off in only two of the 93 cases that they analyze.

Schipper and Smith (1983) also examine the tax and regulatory motives for spin-offs. They argue that a regulated firm may be able to spin-off a subsidiary in a fashion that results in either the parent or the subsidiary escaping the external constraint of regulation. A firm may also be able to spin-off an overseas subsidiary to avoid paying U.S. taxes on the income from that division. Although the benefits to individual firms from such motivations do exist, on average the authors do not find any evidence to support these hypotheses.

Aron (1991) argues that for a large, multi-product firm, the share price is a very noisy signal of any one divisional manager's productivity. A separation through a spin-off is therefore optimal since managerial compensation that is based on the productivity and efficiency of individual divisions improves managers' incentives. More generally, the recontracting effectiveness hypothesis argues that the gains from spin-offs arise from unique contracts after the restructuring that improve the incentives of the different stakeholders of the firm. In a study of 78 spin-offs, Seward and Walsh (1996) find that after the spin-off both the boards of directors and the compensation committees are comprised of a majority of outside directors, suggesting the implementation of efficient internal governance and control mechanisms. They also find that the compensation of the CEO of the spun-off subsidiary is typically performancecontingent. However, they find that the gains around spin-offs are not statistically related to these improvements in contracting efficiency.

Hite and Owers (1983), Schipper and Smith (1983), Daley et al. (1997), and Desai and Jain (1999) contend that gains from spin-offs could arise from improvement in the firm's focus and the elimination of negative synergies between the parent and the subsidiary. Daley, Mehrotra, and Sivakumar, and Desai and Jain document a significant improvement in operating performance in the year after the event for spin-offs that separate divisions that operate in different industries. ${ }^{3}$ Desai and Jain use two other methods to identify focus improving spin-offs, and report that the improved operating and financial performance following spin-offs is robust to the classification scheme. Hite and Owers classify firms based on the reasons given by the firms for the spin-off and find that the subsample where the motivation was improvement in focus exhibits the largest abnormal returns in the period from 50 days prior to the announcement to the completion date of the spin-off. Indirect evidence for the focus improvement motive is also provided by Allen et al. (1995) who examine whether the abnormal returns around spin-offs is a consequence of the correction of a prior mistake. They show that when a spin-off is preceded by the

\footnotetext{
${ }^{3}$ Miller (1995) argues that gains from spin-offs that separate dissimilar units are consistent with an improvement in focus as well as a clientele effect.
} 
acquisition of the division the positive abnormal returns around the spin-off represent the re-creation of value that was destroyed at the time of the earlier acquisition.

The extant empirical evidence therefore indicates that the benefits in a spin-off arise predominantly from the separation of diverse units, which improves focus and eliminates negative synergies between divisions. Cusatis et al. (1993) note significant long-term abnormal returns following spin-offs, but find that these returns are confined to the subsample of firms that are acquired within a threeyear period after the spin-off. They conclude that spin-offs facilitate takeovers by isolating specific divisions, which increases their value to the bidders. However, this increase in value may arise from two distinct sources. It may be due to the elimination of negative synergies between the parent and the subsidiary, in which case a spin-off is valuable because it creates a pure play that is more attractive to the bidder. An alternative explanation is that, since the two entities are separate after a spin-off, the bidder is able to value the separate entities better and thus the standard adverse selection problem that arises under information asymmetry is mitigated.

Nanda and Narayanan (1997) formally develop this information related argument for divestitures through a model of asymmetric information about firm value between the managers of the firm and the market. They assume that the market can observe the aggregate cash flows of the firm but not the individual divisional cash flows, which results in misvaluation of the firm's securities. They develop an equilibrium in which an undervalued firm that requires external capital to finance growth opportunities will resort to raising capital either through a divestiture or after a divestiture, and an overvalued firm will resort to an equity issue without separating its divisions. In the context of spin-offs, since the divestiture does not generate cash inflows to the firm, undervalued firms requiring capital would first engage in a spin-off to attain fair market value for their shares and then issue equity to raise capital.

A spin-off is followed by a detailed disclosure of all individual profit and cost information of the separated divisions in $8 \mathrm{~K}$ and $10 \mathrm{~K}$ statements. After the spin-off the shares trade separately and are tracked by different analysts. These changes obviate the need for a noisy estimation of important division-specific cost and profit information from consolidated financial statements. Gilson et al. (1998) report that after spin-offs there is a significant turnover among analysts who follow the firms' stocks. They also find that there is greater accuracy in analysts' earnings forecasts when there is higher turnover among analysts. Thus, if poor performance by one division has adversely affected the value of other more efficient and profitable divisions, a spin-off will eliminate the undervaluation. Such a correction of valuation would be especially important for firms that in the near future expect to raise external capital to finance their growth opportunities. 
On the other hand, an ordinary disclosure of this information by a combined firm without separating the divisions will not be credible because the firm can manipulate shared costs (which are unobservable by the market) across divisions to maximize the proceeds from the new security issue. ${ }^{4} \mathrm{~A}$ spin-off, however, formally separates the operations and assets of the divisions; no manipulation of costs is possible because there are no shared costs. Hence, the information hypothesis argues that a spin-off enhances value because separating the divisions of a firm into individually operated and traded entities mitigates the information asymmetry in the market about the different divisions' profitability and operating efficiency. Thus, even if there are no negative synergies between divisions, information asymmetry is itself a sufficient motivation for corporations to engage in spin-offs.

There are several testable implications of the information hypothesis. First, firms that engage in spin-offs should have higher levels of information asymmetry about their value compared to other firms. Second, the abnormal returns at the spin-off announcement should be positive, since in equilibrium only undervalued firms engage in spin-offs (Nanda and Narayanan, 1997). Third, if information asymmetry results in undervaluation, then the wealth gains from a spin-off should be positively related to the level of information asymmetry about the firm. Furthermore, by separating the divisions through a spin-off, the individual divisions' operating costs and efficiency are revealed to the market. Thus, the information hypothesis not only predicts a positive share price reaction, but also predicts that the level of information asymmetry will decrease for these firms after the completion of the spin-off. Since firms with different divisions operating within the same industry are likely to have few negative synergies between divisions (Schipper and Smith, 1983; Berger and Ofek, 1995), when these firms undertake a spin-off we expect that information asymmetry is a more important explanation of the shareholder gains from the spin-off.

Since the information hypothesis argues that market value is more transparent after a spin-off, a spin-off may be motivated by a need to raise external capital after the separation. We therefore expect firms that have more growth options in their investment opportunity set but are liquidity constrained to engage in a spin-off. The consequent reduction in information asymmetry lowers the financing costs for the firm. Finally, evidence that a spin-off is followed by either the parent or the subsidiary raising more external capital than before and more external capital than otherwise similar firms will be consistent with the information hypothesis.

\footnotetext{
${ }^{4}$ For evidence of manipulation in transfer pricing and management fees, see Emmanuel and Mehafdi (1994). See also section 7 of Aron (1991).
} 


\section{Data}

\subsection{Data selection}

We identify the sample of firms that undertake spin-offs from the following sources: (i) stock distributions by firms trading on the NYSE, Amex, and Nasdaq, that the Center for Research in Security Prices (CRSP) identifies as spin-offs, (ii) firms in the National Automated Accounting Research System whose annual reports disclose spin-offs, and (iii) news wires and articles on Lexis-Nexis and the Wall Street Journal that report spin-off transactions by firms. The stock distributions that CRSP identifies as spin-offs sometimes include new issues of another class of shares by a firm. The other sources sometimes include stock sales such as equity carve-outs and distributions of common stock in other publicly traded firms that are not subsidiaries of the firm. Since these transactions do not constitute spin-offs we delete them from the sample. We discard return of capital distributions since they are predominantly distributions of income by Real Estate Investment Trusts and do not represent separation of divisions of a firm. Our sample also excludes non-voluntary spin-offs such as those forced through anti-trust regulation. This results in an initial sample of 212 spin-offs.

Finally, to remain in the sample, firms must have earnings forecast data reported on the Institutional Brokers Estimate System (IBES). The IBES coverage requirement arises because, in testing the information hypothesis, we use the errors in analysts' earnings forecasts (both adjusted and unadjusted for earnings volatility) and the standard deviation of these forecasts available through IBES as three of five measures of information asymmetry. This procedure yields a final sample of 118 voluntary corporate spin-offs that were completed between January 1979 and December 1993. The reduction in sample size by 94 firms due to the IBES coverage requirement is large in absolute and relative terms. In Section 4.2, for these 94 firms, we present some financial information and the measures of information asymmetry that do not require earnings forecast data.

The subsidiaries divested in the spin-off transactions are identified by crosschecking the transactions with the details in Moody's Dividend Records, and in news wires and Wall Street Journal articles on Lexis-Nexis. The declaration date, ex-date, record date, and pay date are identified from CRSP and Moody's Dividend Record. We obtain the tax status of the spin-offs from CRSP. Of the 118 spin-offs, 96 are by firms listed on the NYSE, 7 are by firms on the Amex, and 15 are by firms on Nasdaq. Table 1 shows the frequency of spin-offs in each of the sample years along with their exchange listings. CRSP identifies a declaration date for these transactions as the date on which the firm makes a formal declaration of the spin-off, or the date on which the shareholders approve the spin-off. We search the Lexis-Nexis database and Wall Street Journal index at least two years before the CRSP-identified declaration date for the earliest press 
Table 1

Distribution of a sample of 118 firms that completed a spin-off in the period 1979-1993, by announcement year and exchange listing. Spin-offs are identified from the CRSP tapes, the National Automated Accounting Research System, and news wires and articles from Lexis-Nexis and the Wall Street Journal.

Observations by announcement year

Observations by exchange listing on the announcement date

\begin{tabular}{lccccc}
\hline Year & Announcements & & NYSE & AMEX & NASDAQ \\
\cline { 5 - 6 } 1978 & 3 & 3 & 0 & 0 \\
1979 & 1 & 1 & 0 & 0 \\
1980 & 1 & 1 & 0 & 0 \\
1981 & 5 & 4 & 0 & 1 \\
1982 & 4 & 4 & 0 & 0 \\
1983 & 8 & 7 & 0 & 1 \\
1984 & 13 & 9 & 1 & 3 \\
1985 & 14 & 13 & 0 & 1 \\
1986 & 13 & 12 & 1 & 0 \\
1987 & 8 & 5 & 0 & 3 \\
1988 & 17 & 13 & 0 & 0 \\
1989 & 8 & 7 & 1 & 1 \\
1990 & 7 & 7 & 0 & 1 \\
1991 & 4 & 7 & 2 & 0 \\
1992 & 9 & 2 & 1 & 15 \\
1993 & 3 & 96 & 1 & \\
Total no. of firms & 118 & & 7 & \\
\hline
\end{tabular}

announcement of the spin-off. When an announcement is encountered, we search back another year from this date to confirm that there are no earlier announcements.

To control for firm-specific characteristics such as size and industry classification in our empirical tests, we select a control firm for each parent firm in the spin-off sample. For each sample firm, we find a control firm by searching through the list of all firms for which data is available on the CRSP Daily Master file, on the Compustat tapes, and on the IBES tapes. The control firms are restricted to exclude all the parents and subsidiaries in the spin-off sample. From this list of possible controls we choose the firm in the same four-digit SIC code as the sample firm that is closest in market value. Year-end market values for the sample firms and the control firms are computed in the year preceding the spin-off announcement year. The market value of a firm is defined as total assets of the firm minus the book value of its equity plus the market value of its equity. To obtain a reasonable trade-off between industry and size matching, we impose the condition that the market value of the control firm be within $25 \%$ of 
the market value of the sample firm within the four-digit SIC code. If no such match exists, we search for a match at the three-digit SIC level, then at the two-digit level, and finally at the one-digit level. In our sample 70 firms have control firms matched at the four-digit level, 14 firms at the three-digit level, 31 firms at the two-digit level, and 3 firms at the one-digit level.

\subsection{Data characteristics}

We analyze the industry affiliations of the 118 parent firms that engaged in a spin-off and the 126 subsidiaries that were spun-off, and find that the distribution of the subsidiaries across industries is very similar to that of the parent firms. The industry affiliations of the parents and the subsidiaries span 52 distinct two-digit SIC codes. For each firm announcing a spin-off we obtain the reasons stated by the firm for the divestiture from proxy statements, annual reports, and WSJ articles about the spin-off. The motives most often cited are improvement of business focus, improvement of market valuation of the separate entities, and improved access to capital markets. Other motives include basing operational strategy and compensation on division-specific characteristics and facilitating a merger.

The average equity capitalization of the combined firm before the announcement of the spin-off is $\$ 1435$ million, as can be seen in Table 2. To the extent that

Table 2

Market capitalization of the parents and subsidiaries in a sample of 118 firms that completed a spin-off in the period 1979-1993. Spin-offs are identified from the CRSP tapes, the National Automated Accounting Research System, and news wires and articles from Lexis-Nexis and the Wall Street Journal. Market capitalization of combined firm is the product of the total number of shares outstanding and the closing price per share of the firm measured in the year-end prior to the spin-off announcement year. It is denominated in millions of dollars. Market capitalization of parent and Market capitalization of subsidiary are measured similarly but in the month of the completion of the spin-off, and are denominated in millions of dollars. Relative size-before is measured as the ratio of the market capitalization of the subsidiary after the spin-off to the market capitalization of the combined firm before the spin-off. Relative size-after is measured as the ratio of the market capitalization of the subsidiary after the spin-off to the sum of the market capitalizations of the parent and the subsidiary after the spin-off.

\begin{tabular}{lrrrrrr}
\hline Variable & Mean & Min. & \multicolumn{1}{c}{$25 \%$} & Median & $75 \%$ & \multicolumn{1}{c}{ Max. } \\
\hline $\begin{array}{l}\text { Market capitalization of } \\
\text { combined firm }\end{array}$ & 1434.77 & 12.22 & 136.85 & 474.53 & 1987.95 & 15735.90 \\
$\begin{array}{l}\text { Market capitalization of parent } \\
\text { Market capitalization of }\end{array}$ & 1411.16 & 3.06 & 107.90 & 444.65 & 1770.52 & 18551.08 \\
$\begin{array}{l}\text { subsidiary } \\
\text { Relative size - before }\end{array}$ & 0.11 & 1.08 & 32.41 & 111.59 & 211.54 & 5907.02 \\
Relative size - after & 0.215 & 0.006 & 0.065 & 0.137 & 0.396 & 1.939 \\
\hline
\end{tabular}


the value gain from a divestiture is related to the fraction of a firm's operations that is dissociated (Hite and Owers, 1983; Miles and Rosenfeld, 1983), we also examine the size of the divested unit. The average market capitalization of the spun-off subsidiaries, measured in the month of the completion of the spin-off, is $\$ 301$ million. The mean relative size of the spun-off divisions, measured relative to the size of the combined firm before the announcement, is just under $31 \%$. This is comparable to the $29 \%$ relative size in Vijh (1994) for his sample of 113 spin-offs that were completed between 1962 and 1990. This relative size measure, however, may be an inflated estimate of the true relative size because the size of each subsidiary is computed after the spin-off and so includes the effect of the spin-off event, while the capitalization of the combined firm does not reflect the impact of the event. To improve this proxy for relative size, we compute the relative size after the completion of the spin-off, measured as the ratio of the capitalization of the subsidiary to the sum of the capitalizations of the parent and subsidiary after the completion of the spin-off. This relative size measure indicates that on average about $22 \%$ of the combined firm is divested through a spin-off.

Table 3 lists the financial characteristics of the sample and control firms. The average book value of total assets of the sample firms is $\$ 2367$ million, as

\section{Table 3}

Descriptive statistics of the financial variables for a sample of 118 firms that completed a spin-off in the period 1979-1993 and for a sample of 118 size- and industry-matched control firms that did not engage in a spin-off. Spin-offs are identified from the CRSP tapes, the National Automated Accounting Research System, and news wires and articles from Lexis-Nexis and the Wall Street Journal. Total assets is obtained from Compustat and is denominated in billions of dollars. Cashflow from operations is cashflow generated from all operating activities and is measured as a ratio relative to the total assets of the firm. Operating income is sales minus cost of goods sold and other expenses, before depreciation and amortization, and is measured as a ratio relative to the total assets of the firm. Market-to-book ratio is the ratio of (book value of assets - book value of equity + market value of equity) to the book value of assets. Debt ratio is measured as the ratio of short-term plus long-term debt to the total assets of the firm. Unrelated entropy is an index of unrelated diversification of the firm in its operations. For each firm, unrelated entropy is the weighted average of the percentage sales of the various distinct two-digit SIC industry groups within that firm. All variables are measured at year-end of the year prior to the spin-off announcement year.

\begin{tabular}{llllll}
\hline Variable & \multicolumn{2}{l}{ Sample firms } & & \multicolumn{2}{l}{ Control firms } \\
\cline { 2 - 3 } \cline { 6 - 7 } & Mean & Median & & Mean & Median \\
\hline Total Assets (\$ bil.) & 2.3668 & 0.7314 & & 2.1580 & 0.5269 \\
Cashflow from operations & 0.1044 & 0.0954 & & 0.1366 & 0.1037 \\
Operating income & 0.1312 & 0.1232 & & 0.1648 & 0.1287 \\
Market-to-book ratio & 1.3410 & 1.1675 & & 1.5219 & 1.1554 \\
Debt ratio & 0.2867 & 0.2752 & & 0.2380 & 0.2197 \\
Unrelated entropy & 0.5717 & 0.5909 & & 0.3103 & 0.1734 \\
\hline
\end{tabular}


compared to $\$ 2158$ million for the control firms. The sample firms generate less internal cash flow, about $10.5 \%$ of total assets, compared to nearly $14 \%$ for the control firms. The typical firm that engages in a spin-off has a total debt ratio of $29 \%$ while its size- and industry-adjusted control is more conservatively financed with a debt ratio of $24 \%$. Perhaps the most striking difference between the firms that undertake spin-offs and those that do not is in their level of diversification in operations. Following Palepu (1985) we measure unrelated diversification using the unrelated entropy index. For each firm, unrelated entropy is the weighted average of the percentage sales of the various distinct two-digit SIC industry groups within that firm. ${ }^{5}$ The sample firms are more diversified with a mean unrelated entropy of 0.572 compared to the control firms which have a mean unrelated entropy of 0.310 . This difference is more pronounced in the medians.

\subsection{Measures of information asymmetry}

We use five different measures of information asymmetry in the empirical analysis. The first is the forecast error in earnings measured before the announcement of the spin-off. Analysts' earnings forecasts are obtained from IBES, which reports a monthly mean, median, and standard deviation of the forecasts for each firm based on the analysts' estimates that are submitted that month. For each firm in the sample (and for its matched control), the fiscal year prior to the announcement of the spin-off serves as the year of observation. The mean monthly earnings forecast for the last month of that fiscal year is defined as the predicted earnings. Following Christie (1987), we measure forecast error as the ratio of the absolute difference between the forecast earnings and the actual earnings per share to the price per share at the beginning of the month. Firms with larger levels of information asymmetry between the managers and the outside market about their cash flows and value are expected to have higher forecast errors.

The use of errors in analysts' forecasts of earnings as a measure of information asymmetry surrounding a firm is especially appropriate given the evidence in Elton et al. (1984). They undertake a detailed analysis of the forecast errors in the earnings of a wide cross-section of firms. They examine the size, pattern, and source of these errors by partitioning them into errors derived from mispredicting economy-wide factors, industry-wide factors, and firm-specific factors. They show that the errors decrease as the predictions get closer to the end of the fiscal year and find that nearly $84 \%$ of the forecast error in the final month can be

\footnotetext{
${ }^{5}$ Desai and Jain (1999) also use a measure similar to the unrelated entropy index. Their Herfindahl index measure is constructed using the sales of different divisions in a firm but does not distinguish between divisions operating in different two-digit SIC industry groups within a firm.
} 
attributed to misestimation of firm-specific factors rather than to misestimation of economy or industry factors. This evidence suggests that analysts' forecast errors are a particularly appropriate proxy for the level of information asymmetry about a firm. ${ }^{6}$

The second measure of information asymmetry is the standard deviation of forecasts, which is measured as the standard deviation of all earnings forecasts made in the last month of the fiscal year preceding the spin-off announcement year. This variable represents the dispersion among analysts about a consensus estimate of the forecast. Since disagreement among analysts is an indication of the lack of available information about the firm, we use this standard deviation as another metric of the level of information asymmetry about the firm.

One criticism of the use of forecast errors as a measure of information asymmetry is that some firms may have higher forecast errors because they have more volatile earnings and not because they have higher levels of information asymmetry. Thus, the forecast errors may be correlated with the riskiness of the firm. To control for the correlation between forecast errors and earnings volatility, we compute a third measure of information asymmetry, the normalized forecast error, which is defined as the ratio of the forecast error in earnings to the earnings volatility of the firm. Earnings volatility is the standard deviation of the firm's detrended quarterly earnings in the five-year period before the announcement of the spin-off.

Following Dierkens (1991), we use the volatility in abnormal returns around earnings announcements as the fourth measure of information asymmetry about each firm. This announcement reaction variable is measured as the standard deviation of the three-day abnormal returns around the announcement of quarterly earnings, over all the quarterly earnings announcements during the five years preceding the announcement of the spin-off. The quarterly earnings announcement dates are obtained from Compustat. For firm-quarters with missing earnings announcement dates, we obtain the dates from the Wall Street Journal Index. We use the CRSP value-weighted index to compute the marketadjusted abnormal returns around the announcement dates. A strong positive or negative reaction by the market around an information-revealing event such as an earnings announcement suggests that information asymmetry is high for these firms. As in Dierkens (1991), the standard deviation of the abnormal

\footnotetext{
${ }^{6}$ Fried and Givoly (1982) and O'Brien (1988) show that analysts are overly optimistic at the beginning of the fiscal year and therefore tend to revise their forecasts downward as the year progresses. Thus, forecast errors may include a component due to this 'optimism bias' that may confound the use of this measure as a proxy for information asymmetry. This is not a problem in our study for two reasons: for all firms, the errors are computed in a common month, the last month of the fiscal year, thereby standardizing the impact of this bias, and forecasts in the last month of the fiscal year have been shown (O'Brien, 1988) to be the most accurate.
} 
returns around earnings announcements, which measures the dispersion in the market reaction, is used as a metric of information asymmetry.

Finally, following Bhagat et al. (1985), Blackwell et al. (1990), and Krishnaswami et al. (1999), we use the residual volatility in daily stock returns as the fifth proxy for information asymmetry. Information asymmetry about a firm is high when managers have a relatively large amount of value-relevant, firm-specific information that is not shared by the market. Investors bear some firm-specific uncertainty until this information is revealed to the market. If the investors and the firm's managers are equally well-informed about the economy-wide factors influencing the firm's value, then the residual volatility in the firm's stock returns captures the information asymmetry between the investors and the managers about firm-specific information. The residual standard deviation is the dispersion in the market-adjusted daily stock returns in the year preceding the announcement of the spin-off. This residual standard deviation variable captures the firm-specific uncertainty that remains after removing from the total uncertainty the uncertainty that is common to the firm's insiders and the market. ${ }^{7}$ We expect firms with higher information asymmetry about their cash flows and value to have higher residual volatility in their stock returns.

\section{Empirical results}

\subsection{Abnormal returns}

Prior studies find positive abnormal returns around the announcement of spin-offs. We confirm these returns by employing the event-study methodology used by Dodd and Warner (1983). We estimate a market model over a 155-day period ending 45 days before the announcement of the spin-off. The CRSP value-weighted index is used as a proxy for the market portfolio. Table 4 summarizes the abnormal returns over different time intervals ar ound the announcement date for the sample of firms that engaged in spin-offs. We obtain a significant two-day cumulative abnormal return of $3.15 \%$ in the window $(-1,0)$, which is consistent with the findings of earlier studies on spin-offs. Significant abnormal returns of $1.80 \%$ and $3.28 \%$ are also found on day 0 and in the window $(-1,+1)$, respectively.

\subsection{Univariate tests}

We compare the levels of information asymmetry of the sample firms with those of their size- and industry-matched control firms. If firms that engage in

\footnotetext{
${ }^{7}$ Admittedly, this variable may be an overestimate of the true measure of information asymmetry, since it also contains the impact of information that was previously unavailable to both the investors and the managers.
} 
Table 4

Cumulative abnormal returns over selected intervals for a sample of 118 firms that completed a spin-off during the period 1979-1993. Spin-offs are identified from the CRSP tapes, the National Automated Accounting Research System, and news wires and articles from Lexis-Nexis and the Wall Street Journal. Abnormal returns are calculated using the market model parameters estimated over a 155-day period ending 45 days before the announcement date. The CRSP value-weighted index is used in the market model to compute betas. The abnormal returns are cumulated in the intervals. The percentage positive is the ratio of the number of firms with positive abnormal returns to the total number of firms. The generalized sign test is used to test the significance of the percentage of firms with positive abnormal returns.

\begin{tabular}{lcccc} 
Interval & \multicolumn{2}{l}{ Cumulative abnormal returns for sample } & \\
\cline { 2 - 5 } & Mean \% & $t$-statistic & Median \% & $\begin{array}{l}\text { Percentage } \\
\text { positive }\end{array}$ \\
\hline-30 to -6 & 1.56 & 0.79 & 0.17 & 51 \\
-5 to -1 & 0.57 & 1.35 & 0.51 & $53^{\mathrm{a}}$ \\
-1 to 0 & 3.15 & $5.62^{\mathrm{a}}$ & 1.92 & $73^{\mathrm{a}}$ \\
0 & 1.80 & $3.20^{\mathrm{a}}$ & 0.77 & $62^{\mathrm{a}}$ \\
-1 to +1 & 3.28 & $4.51^{\mathrm{a}}$ & 2.55 & $68^{\mathrm{a}}$ \\
+1 to +5 & -0.51 & -0.70 & -0.44 & 44 \\
+6 to +30 & -0.84 & 0.79 & 0.32 & 51 \\
\hline
\end{tabular}

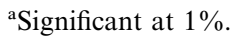

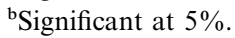

${ }^{\mathrm{c}}$ Significant at $10 \%$.

spin-offs are subject to greater information dissemination problems, we should observe higher levels of information asymmetry for the sample firms relative to the control firms before the spin-off. Panel A of Table 5 summarizes the difference in the information asymmetry variables between the sample and control firms before the announcement of the spin-off. The results are consistent with the information hypothesis. The average forecast error for the sample firms is 0.0433 , which is more than three times that of the controls. The Wilcoxon's signed rank test of the difference in the means across the sample and control firms and the Median Scores test for the difference in the medians indicate that the forecast errors of the two groups are significantly different from each other at the $1 \%$ significance level. These results also persist through the other four measures of information asymmetry.

If the separation of a firm into individually operated units with separately traded shares improves the accuracy of information processing about the individual divisions of the firm, then the level of information asymmetry should decrease after the completion of the spin-off. To examine this we compute the information asymmetry variables after the completion of the spin-off. The after-event forecast error is defined as the ratio of the absolute value of the difference between the actual earnings and the forecast earnings to the price per 
Table 5

Summary statistics of the information asymmetry variables for a sample of 118 firms that completed a spin-off in the period 1979-1993 and for a sample of 118 size- and industry-matched control firms that did not engage in a spin-off. Spin-offs are identified from the CRSP tapes, the National Automated Accounting Research System, and news wires and articles from Lexis-Nexis and the Wall Street Journal. The forecast errors are defined as the ratio of the absolute value of the difference between the actual earnings and the forecast earnings to the price per share at the beginning of the month. The before-event forecast errors are measured in the last month of the fiscal year before the announcement of the spin-off. The after-event forecast errors are measured in the last month of the first fiscal year after the completion of the spin-off. The standard deviation of forecasts measures the dispersion in the analysts' earnings forecasts in the month in which the forecast errors are computed. The before-event normalized forecast errors are measured as the ratio of the beforeevent forecast errors to the standard deviation of the detrended quarterly earnings in the five years before the announcement of the spin-off. The after-event normalized forecast errors are measured as the ratio of the after-event forecast errors to the standard deviation of the detrended quarterly earnings in the two years after the completion of the spin-off. The before-event announcement reaction variable is the standard deviation of the three-day cumulative abnormal returns around the announcements of quarterly earnings in the five year period before the announcement of the spin-off. The after-event announcement reaction variable is the standard deviation of the three-day cumulative abnormal returns around the announcements of quarterly earnings in the two year period after the completion of the spin-off. The before-event residual standard deviation is the dispersion in the market-adjusted daily stock returns in the year preceding the spin-off announcement. The after-event residual standard deviation is the dispersion in the market-adjusted daily stock returns in the year after the spin-off completion. The results of the nonparametric Wilcoxon Signed Rank test for the difference in the means and the Median Scores test for the difference in the medians are specified in the panels.

Panel A: Level of before-event information asymmetry for sample and control firms

\begin{tabular}{|c|c|c|c|c|c|c|}
\hline \multirow[t]{2}{*}{ Variables } & \multicolumn{2}{|c|}{ Sample firms } & \multicolumn{2}{|c|}{ Control firms } & \multicolumn{2}{|c|}{ Difference } \\
\hline & Mean & Median & Mean & Median & Mean & Median \\
\hline Forecast error & 0.0433 & 0.0109 & 0.0132 & 0.0047 & $0.0301^{\mathrm{a}}$ & $0.0062^{\mathrm{a}}$ \\
\hline Std. deviation of forecasts & 0.2383 & 0.1200 & 0.1051 & 0.0800 & $0.1332^{\mathrm{a}}$ & $0.0400^{\mathrm{a}}$ \\
\hline Normalized forecast error & 0.1282 & 0.0416 & 0.0441 & 0.0173 & $0.0841^{\mathrm{a}}$ & $0.0243^{\mathrm{a}}$ \\
\hline Announcement reaction & 0.2508 & 0.0536 & 0.0424 & 0.0391 & $0.2084^{b}$ & $0.0145^{\mathrm{b}}$ \\
\hline Residual std. deviation & 0.0795 & 0.0258 & 0.0230 & 0.0199 & $0.0565^{\mathrm{b}}$ & $0.0059^{\mathrm{b}}$ \\
\hline
\end{tabular}

Panel B: Level of information asymmetry for sample firms before and after the spin-off

\begin{tabular}{|c|c|c|c|c|c|c|}
\hline \multirow[t]{2}{*}{ Variables } & \multicolumn{2}{|c|}{ Before-event } & \multicolumn{2}{|c|}{ After-event } & \multicolumn{2}{|c|}{ Difference } \\
\hline & Mean & Median & Mean & Median & Mean & Median \\
\hline Forecast error & 0.0433 & 0.0109 & 0.0095 & 0.0022 & $0.0338^{\mathrm{a}}$ & $0.0087^{\mathrm{a}}$ \\
\hline Std. deviation of forecasts & 0.2383 & 0.1200 & 0.1269 & 0.0900 & $0.1114^{\mathrm{b}}$ & $0.0300^{\mathrm{b}}$ \\
\hline Normalized forecast error & 0.1282 & 0.0416 & 0.0567 & 0.0180 & $0.0715^{\mathrm{b}}$ & $0.0236^{\mathrm{b}}$ \\
\hline Announcement reaction & 0.2508 & 0.0536 & 0.0415 & 0.0374 & $0.2093^{\mathrm{a}}$ & $0.0162^{\mathrm{a}}$ \\
\hline Residual std. deviation & 0.0795 & 0.0258 & 0.0227 & 0.0195 & $0.0568^{\mathrm{b}}$ & $0.0063^{\mathrm{a}}$ \\
\hline
\end{tabular}

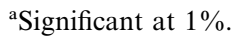

${ }^{\mathrm{b}}$ Significant at $5 \%$.

${ }^{\mathrm{c} S}$ Significant at $10 \%$. 
share at the beginning of the month, and is measured in the last month of the first fiscal year after the completion of the spin-off. The after-event standard deviation of forecasts is also measured in the same month as the after-event forecast errors. The after-event normalized forecast error is the after-event forecast error normalized by the standard deviation of the detrended quarterly earnings in the two years after the spin-off completion. The after-event announcement reaction variable measures the standard deviation of the three-day abnormal returns around the announcements of quarterly earnings in the two year period after the completion of the spin-off. Finally, we measure the after-event residual standard deviation as the dispersion in the market-adjusted daily stock returns in the year after the completion of the spin-off.

The summary statistics of the information asymmetry variables measured before and after the spin-off are reported in Panel B of Table 5. The evidence indicates that the forecast errors decrease significantly (by over $78 \%$ ) after the event. The mean and median difference between the before-event forecast errors and the after-event forecast errors are significantly different from zero at the $1 \%$ level, concurring with our expectations. The other four measures of information asymmetry also significantly decrease after the spin-off.

If information asymmetry results in undervaluation of the firm, and if spinoffs mitigate information asymmetry, then firms with higher levels of information asymmetry should exhibit higher abnormal returns upon the announcement of spin-offs. To examine this implication, we sort the sample firms into quartiles (highest to lowest) based on their level of information asymmetry. We then examine the quartiles to see whether the abnormal returns are significantly higher in the top quartile relative to the bottom quartile. As shown in Table 6, the average abnormal returns are significantly higher for the group of firms in the top quartile. For instance, when the quartiles are based on the forecast error variable, the top quartile mean two-day CAR is $4.11 \%$, while it is $2.28 \%$ in the bottom quartile. This difference is significant at the $5 \%$ level. Furthermore, the abnormal returns decrease monotonically from the group with the highest forecast error to the group with the lowest forecast error. Similarly, in the quartile classification based on the standard deviation of the forecasts, the top quartile median CAR is $4.88 \%$, the bottom quartile median CAR is $0.38 \%$, and the difference is significant at the $1 \%$ level.

We also analyze the financial and information asymmetry variables for the 94 firms (in our original sample of 212) that do not have analysts' forecast data. We find that these firms are smaller in size with similar growth opportunities but with less internally generated cashflow, and are less diversified than our primary sample of 118 firms. This evidence suggests that for these firms information asymmetry is likely to be a more important motive for a spin-off than improving focus. Consistent with this conjecture, the two measures of information asymmetry that are available for these firms indicate that the level of information asymmetry is higher for these firms than for the primary sample of 118 firms 
Table 6

Abnormal returns for a sample of 118 firms that completed a spin-off in the period 1979-1993, sorted based on the level of information asymmetry. Spin-offs are identified from the CRSP tapes, the National Automated Accounting Research System, and news wires and articles from Lexis-Nexis and the Wall Street Journal. Abnormal returns are calculated using the market model parameters estimated over a 155-day period ending 45 days before the announcement date. The CRSP valueweighted index is used in the market model to compute betas. The abnormal returns are the cumulative abnormal returns measured over the interval $(-1,0)$. The forecast errors are defined as the ratio of the absolute value of the difference between the actual earnings and the forecast earnings to the price per share at the beginning of the month, and are measured in the last month of the fiscal year before the announcement of the spin-off. The standard deviation of the forecasts measure the dispersion in the analysts' earnings forecasts in the month in which the forecast errors are computed. The normalized forecast errors are measured as the ratio of the forecast errors to the standard deviation of the detrended quarterly earnings in the five years before the announcement of the spin-off. The announcement reaction variable is the standard deviation of the three-day cumulative abnormal returns around the announcements of quarterly earnings in the five year period before the announcement of the spin-off. The residual standard deviation is the dispersion in the marketadjusted daily stock returns in the year preceding the spin-off announcement. The results of the nonparametric Mann-Whitney Rank test for difference in the means and the Median Scores test for the difference in the medians are specified in the panel.

Variable Quartile 1 Quartile 2 Quartile 3 Quartile 4 Difference

Q1 - Q4

$\begin{array}{llllll}\begin{array}{l}\text { Forecast error } \\ \text { Mean }\end{array} & 4.11 & 3.15 & 3.01 & 2.28 & 1.83^{\mathrm{b}} \\ \quad \text { Median } & 3.31 & 2.29 & 0.88 & 1.03 & 2.28^{\mathrm{b}} \\ \quad \text { Number of observations } & 29 & 29 & 29 & 29 & \\ \begin{array}{l}\text { Std. deviation of forecasts } \\ \quad \text { Mean }\end{array} & 4.50 & 3.68 & 2.53 & 1.69 & 2.81^{\mathrm{a}} \\ \quad \text { Median } & 4.88 & 2.68 & 1.28 & 0.38 & 4.42^{\mathrm{a}} \\ \quad \text { Number of observations } & 29 & 30 & 29 & 29 & \\ \text { Normalized forecast error } & & & & & \\ \quad \text { Mean } & 4.45 & 2.82 & 2.67 & 1.74 & 2.71^{\mathrm{a}} \\ \quad \text { Median } & 2.89 & 1.69 & 1.32 & 0.31 & 2.58^{\mathrm{a}} \\ \quad \text { Number of observations } & 28 & 27 & 27 & 28 & \\ \text { Announcement reaction } & & & & & \\ \quad \text { Mean } & 4.70 & 2.77 & 2.93 & 2.64 & 2.06^{\mathrm{b}} \\ \quad \text { Median } & 3.50 & 1.72 & 1.56 & 0.60 & 2.90^{\mathrm{a}} \\ \quad \text { Number of observations } & 27 & 27 & 27 & 27 & \\ \text { Residual std. deviation } & & & & & \\ \quad \text { Mean } & 4.25 & 4.65 & 2.32 & 1.67 & 2.58^{\mathrm{b}} \\ \quad \begin{array}{l}\text { Median } \\ \text { Number of observations }\end{array} & 2.29 & 3.78 & 1.40 & 0.38 & 1.91^{\mathrm{c}} \\ \end{array}$

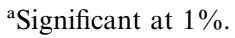

${ }^{\mathrm{b}}$ Significant at $5 \%$.

${ }^{\mathrm{c}}$ Significant at $10 \%$. 
(and their control firms). As with the primary sample, we find that information asymmetry is positively related to the abnormal returns, and the level of information asymmetry decreases following a spin-off. We therefore, believe that the reduction in sample size due to the analysts' forecast data requirement does not affect our inferences. These results are available from the authors upon request.

Schipper and Smith (1983) argue that elimination of negative synergies may be a motive for corporate spin-offs. Accordingly, they find that a significant fraction of their sample of spin-offs contains firms for which the separated subsidiary is in a different industry. We examine this theory by classifying the sample into same-industry and cross-industry spin-offs using a criterion that is similar to the one used by Daley et al. (1997). We define a cross-industry spin-off as one in which the parent divests a subsidiary with a two-digit SIC code that is different from the primary two-digit SIC code of the parent. Consistent with the elimination of negative synergies hypothesis, Panel A of Table 7 reports that the mean announcement period abnormal return is $3.59 \%$ for the subsample of cross-industry spin-offs, while it is only $1.86 \%$ for the subsample of sameindustry spin-offs. This difference is significant at the $5 \%$ level. This result is similar to the finding in Daley et al. (1997), who further report that the long-term operating and financial performance is better for the cross-industry group than for the same-industry group.

Stock analysts typically have industry preferences and tend to track firms in one or a few specific industries. When these analysts encounter firms with divisions in different industries, their valuation of the unfamiliar divisions is likely to be less accurate, leading to higher forecast errors for such firms. This reasoning is emphasized in a Business Week article discussing the Westinghouse spin-off in which the author argues that "Wall Street couldn't figure out how to value a $\$ 9.5$ billion company with one foot in a TV studio and the other in a nuclear-waste dump" (see Baker, 1996). Also, if analysts evaluate a firm based predominantly on its primary industry affiliation, then their earnings forecasts of firms with multiple lines of business will contain larger errors. In a random sample of firms, one therefore expects higher forecast errors for firms that operate in more than one industry. The same need not be true, however, for the sample of firms that engage in spin-offs, because, if the adverse effect of information asymmetry were an important motive for spin-offs, we would expect even same-industry spin-offs to have high levels of information asymmetry. Evidence that there is no significant difference in the information asymmetry levels between the sub-samples of same and cross-industry spin-offs will therefore be consistent with the information hypothesis. Evidence that there is no correlation between the variables that measure information asymmetry and the variables that measure negative synergies across divisions will indicate that our measures of information asymmetry are not proxying for negative synergies. 


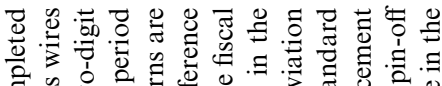

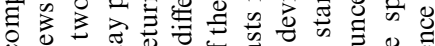

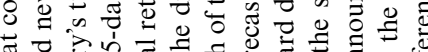

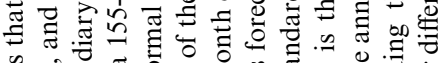

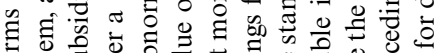

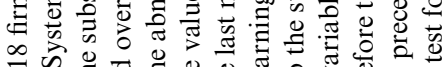

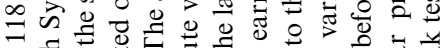

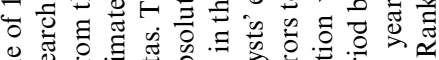

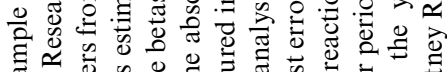

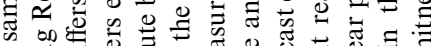

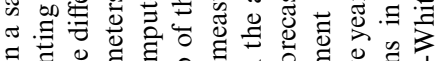

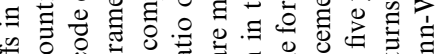

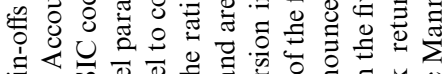

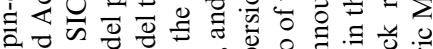
क

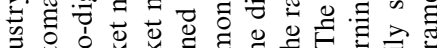

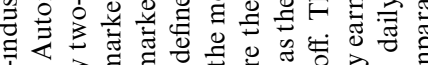

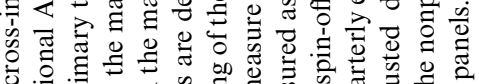
o.

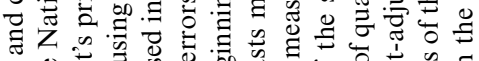

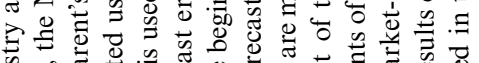
की

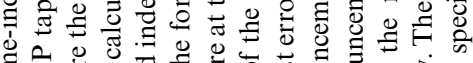

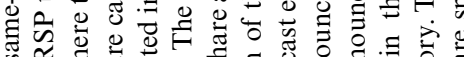

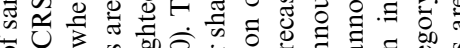
०

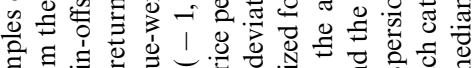

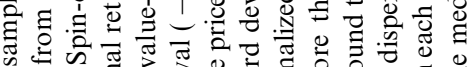

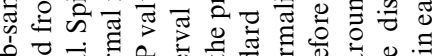

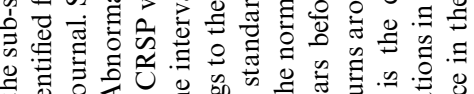

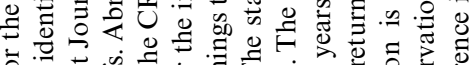

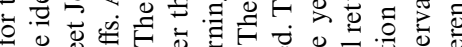

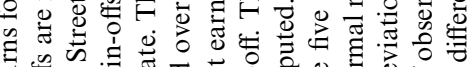

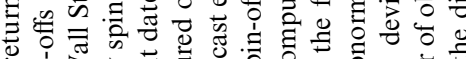

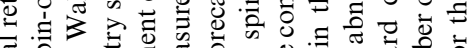

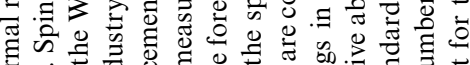

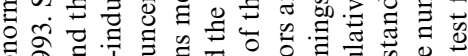
है

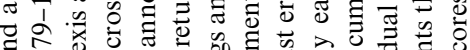

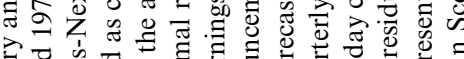

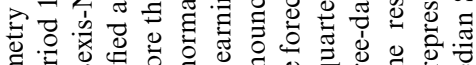

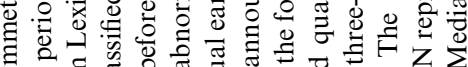
हाँ

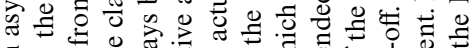

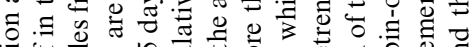

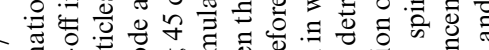

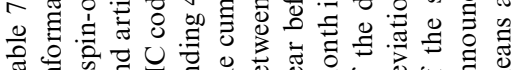

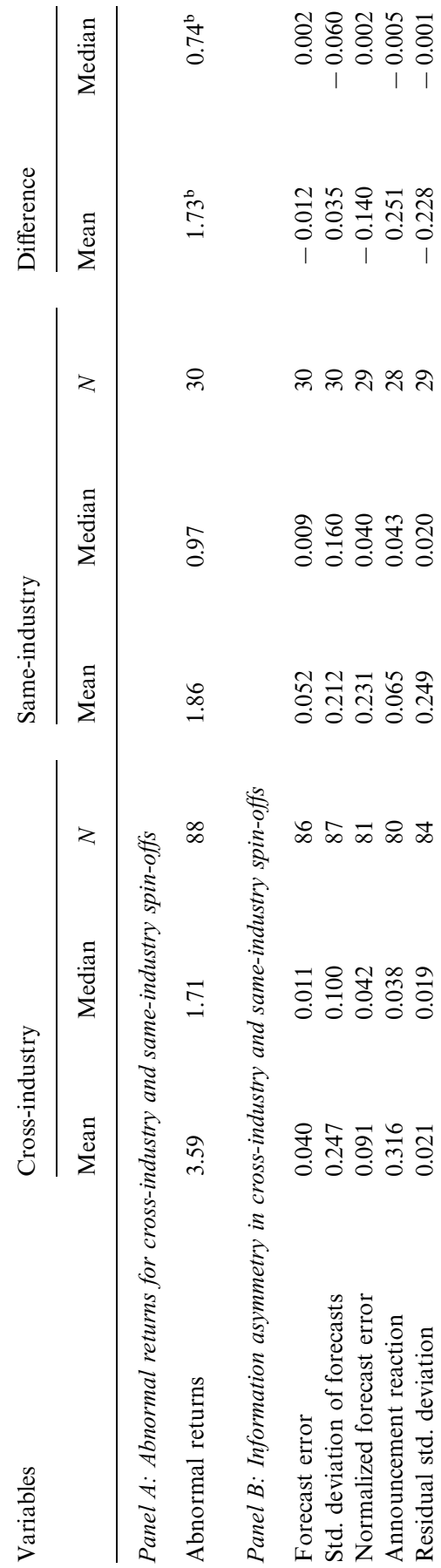




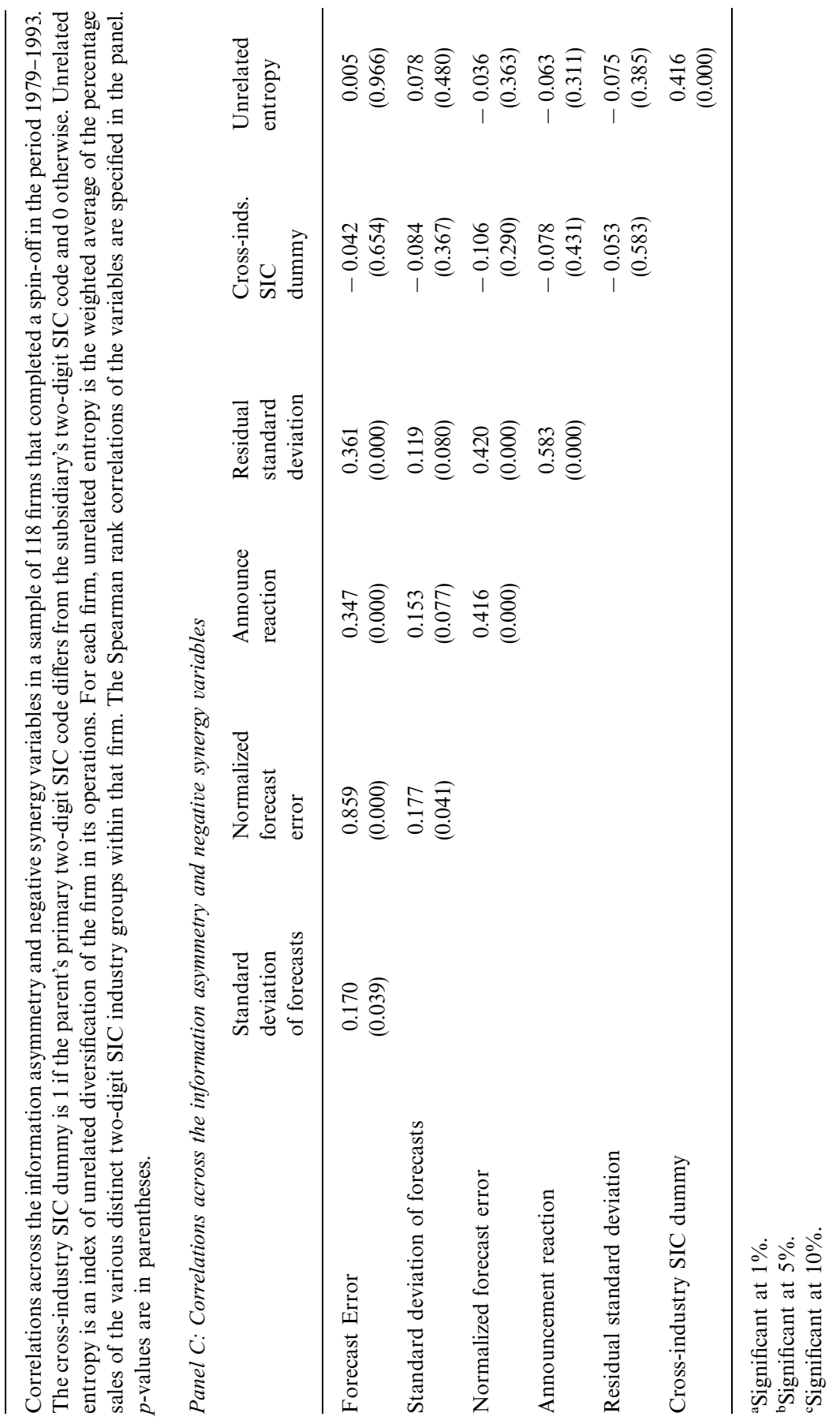


The results in Panel B of Table 7 conform to the implications of the information hypothesis. They indicate that the difference in the mean and median level of information asymmetry between cross-industry and same-industry spin-offs is not statistically significant. The mean forecast error for the cross-industry subsample is 0.040 , as compared to 0.052 for the same-industry subsample, but this difference is not statistically significant. The evidence is similar across the other measures of information asymmetry.

Panel C of Table 7 presents the Spearman correlation coefficients for the five measures of information asymmetry and the two measures of negative synergies. Each of the pairwise correlations among the five information asymmetry variables is positive and statistically significant. With the exception of the standard deviation of forecasts variable, the information asymmetry variables have pairwise correlations that are significantly positive at the $1 \%$ level. The standard deviation of forecasts is correlated with the forecast error and the normalized forecast error variables at the $5 \%$ level of significance, and with the announcement reaction and residual standard deviation variables at the $10 \%$ level. The two negative synergy variables, the cross-industry SIC dummy and the unrelated entropy index, are significantly correlated at the $1 \%$ level with a coefficient of 0.416 . Finally, none of the five information asymmetry variables is significantly correlated with either of the two measures of negative synergies. The information asymmetry variables therefore do not seem to be proxying for negative synergies across divisions of a firm.

To identify the incremental impact of information asymmetry on shareholder gains around spin-offs, we also examine other factors that may be used as controls in the regression analysis. Cusatis et al. (1993) find that the post-event abnormal long-term performance of spin-offs is confined to the subsample of firms that were acquired after the spin-off. In this context, we use the motives stated in proxy statements and news articles to classify the sample of spin-offs into two groups, one containing firms that state the facilitation of a merger or acquisition as a motive, and the other containing the remaining firms. We expect higher abnormal returns for the subsample with a merger motive. The results in Panel A of Table 8, however, indicate that the average abnormal returns for the subsample with a merger motive is $4.09 \%$ compared to a statistically indistinguishable $3.09 \%$ for the other subsample.

Regulation may be another motive for firms to engage in spin-offs. Regulated subsidiaries can bring the parent under their regulatory umbrella, which restrains the parent in its operations. The separation of a regulated subsidiary (parent) from the parent (subsidiary) through a spin-off eliminates this external constraint and may be a source of the gains generated around spin-off announcements. We classify sample firms as potentially having a regulation motive if either the parent or the subsidiary, but not both, is in an unregulated industry based on four-digit SIC codes. Panel B of Table 8 reveals no significant difference in the abnormal returns of the subsamples of firms with and without 
Table 8

Summary of abnormal returns for a sample of 118 firms that completed a spin-off in the period 1979-1993, sorted based on different characteristics of the sample firms. Spin-offs are identified from the CRSP tapes, the National Automated Accounting Research System, and news wires and articles from Lexis-Nexis and the Wall Street Journal. The motives for each spin-off are obtained from proxy statements and from Wall Street Journal articles. A merger motive is said to exist if the firm states that the spin-off is intended to facilitate the merger or acquisition of either the parent or the subsidiary with another firm. A regulation motive is said to exist if either the parent or the subsidiary, but not both, is in an unregulated industry after the spin-off. Taxable spin-offs are identified from their distribution codes on CRSP. Abnormal returns are calculated using the market model parameters estimated over a 155 -day period ending 45 days before the announcement date. The CRSP value-weighted index is used in the market model to compute betas. The abnormal returns are the cumulative abnormal returns measured over the interval $(-1,0)$. $\mathrm{N}$ represents the number of observations in each category. The results of the nonparametric Mann-Whitney Rank test for difference in the means and the Median Scores test for the difference in the medians are specified in the panels.

Panel A: Abnormal returns for sub-samples based on merger motive

\begin{tabular}{|c|c|c|c|c|c|c|c|c|}
\hline \multirow[t]{2}{*}{ Variables } & \multicolumn{3}{|c|}{ Merger motive } & \multicolumn{3}{|c|}{ No merger motive } & \multicolumn{2}{|c|}{ Difference } \\
\hline & Mean & Median & $N$ & Mean & Median & $N$ & Mean & Median \\
\hline Abnormal returns & 4.09 & 3.29 & 7 & 3.09 & 1.83 & 111 & 1.00 & 1.46 \\
\hline
\end{tabular}

Panel B: Abnormal returns for sub-samples based on regulation motive

\begin{tabular}{|c|c|c|c|c|c|c|c|c|}
\hline & \multicolumn{3}{|c|}{ Regulation motive } & \multicolumn{3}{|c|}{ No regulation motive } & \multicolumn{2}{|c|}{ Difference } \\
\hline & Mean & Median & $N$ & Mean & Median & $N$ & Mean & Median \\
\hline Abnormal returns & 3.07 & 1.71 & 28 & 3.17 & 1.96 & 90 & -0.10 & -0.25 \\
\hline
\end{tabular}

Panel C: Abnormal returns for sub-samples based on tax status

\begin{tabular}{|c|c|c|c|c|c|c|c|c|}
\hline \multirow[t]{2}{*}{ Variables } & \multicolumn{3}{|c|}{ Taxable } & \multicolumn{3}{|c|}{ Nontaxable } & \multicolumn{2}{|c|}{ Difference } \\
\hline & Mean & Median & $N$ & Mean & Median & $N$ & Mean & Median \\
\hline Abnormal returns & 1.21 & 0.19 & 15 & 3.43 & 2.09 & 103 & $-2.22^{\mathrm{a}}$ & $-1.90^{\mathrm{a}}$ \\
\hline
\end{tabular}

${ }^{\mathrm{a}}$ Significant at $1 \%$.

${ }^{\mathrm{b}}$ Significant at $5 \%$.

${ }^{\mathrm{c}}$ Significant at $10 \%$.

a regulation motive. Thus, consistent with the results in Schipper and Smith (1983), regulation does not appear to be a significant motive for spin-offs. Finally, we also examine whether the tax status of a spin-off explains a portion of the announcement period gains. We find that spin-offs ruled to be taxable distributions by the IRS earn two-day abnormal returns of $1.21 \%$, while the 
nontaxable group earns $3.43 \%$ (see Panel C of Table 8), consistent with the expectation that taxation imposes a penalty on shareholders' gains. This difference is statistically significant at the $1 \%$ level.

In Table 9 we present evidence on capital-raising activities by the sample and control firms for up to three years before and three years after the completion of a spin-off. In Panel A we report the frequency of equity issues by the firms in each year. The equity issues are identified from the Security Data Corporation's Global financings database. We find that in each of the three years before a spin-off the frequency of equity issuance for the sample firms is statistically indistinguishable from that of their size- and industry-matched control firms. In

Table 9

Capital raising activity in a sample of 118 firms that completed a spin-off in the period 1979-1993 and in a sample of 118 size- and industry-matched control firms that did not engage in a spin-off. Spin-offs are identified from the CRSP tapes, the National Automated Accounting Research System, and news wires and articles from Lexis-Nexis and the Wall Street Journal. Years $-1,-2$, and -3 are measured relative to the spin-off announcement year, while Years $+1,+2$, and +3 are measured relative to the spin-off completion year. For each firm, the frequency of equity issues is obtained from the Security Data Corporation's Global Financings database. Equity issues in the years $+1,+2$, and +3 include issues by the parent firms and their separated subsidiaries. A one-tailed proportions test is used to test the statistical significance of the increase in frequency of equity issues following spin-offs compared to the frequency of equity issues before the announcement, and compared to the frequency of equity issues in the control sample. The mean [median] dollar amounts of equity and debt raised in each year by the sample and control firms are obtained from Compustat and are specified in millions of dollars. In the years following the completion of the spin-off, the equity and debt amounts reported include capital raised by the parent firms and their separated subsidiaries. The results of the nonparametric Mann-Whitney Rank test for difference in the mean equity and debt amounts between the relevant groups and the results of the Median Scores test for the difference in the median equity and debt amounts between the relevant groups are specified in the panel.

Panel A: Frequency of equity issues by the sample and control firms

Year

Frequency of equity issues

Difference

Sample Firms $\quad$ Control firms $\quad \overline{\text { Sample }- \text { Control }}$

\begin{tabular}{lrrr}
\hline Year -3 & 6 & 8 & -2 \\
Year -2 & 9 & 10 & -1 \\
Year -1 & 11 & 10 & 1 \\
Year +1 & 14 & 7 & $7^{\mathrm{c}}$ \\
Year +2 & 16 & 10 & $6^{\mathrm{c}}$ \\
Year +3 & 7 & & 1 \\
Year after - Year before & 3 & & \\
[Years +1 and +2$]-$ & & & \\
[Years -1 and -2$]$ & $10^{\mathrm{c}}$ & & \\
[Years $+1,+2$, and +3$]-$ & &
\end{tabular}


Table 9. Continued.

Panel B: Dollar amounts of debt and equity raised by the sample and control firms

\begin{tabular}{|c|c|c|c|c|c|c|}
\hline \multirow[t]{3}{*}{ Year } & \multicolumn{4}{|c|}{ Capital raised (\$ millions) } & \multicolumn{2}{|l|}{ Difference } \\
\hline & \multicolumn{2}{|c|}{ Sample firms } & \multicolumn{2}{|c|}{ Control firms } & \multicolumn{2}{|c|}{ Sample - Control } \\
\hline & Equity & Debt & Equity & Debt & Equity & Debt \\
\hline Year -3 & $\begin{array}{l}11.439 \\
{[1.112]}\end{array}$ & $\begin{array}{l}168.046 \\
{[30.514]}\end{array}$ & $\begin{array}{l}18.959 \\
{[0.883]}\end{array}$ & $\begin{array}{l}97.651 \\
{[5.410]}\end{array}$ & $\begin{array}{r}-7.520 \\
{[0.229]}\end{array}$ & $\begin{array}{c}70.395^{\mathrm{a}} \\
{[25.104]^{\mathrm{a}}}\end{array}$ \\
\hline Year -2 & $\begin{array}{l}14.844 \\
{[0.857]}\end{array}$ & $\begin{array}{l}234.250 \\
{[19.293]}\end{array}$ & $\begin{array}{l}26.062 \\
{[1.032]}\end{array}$ & $\begin{array}{l}78.529 \\
{[8.110]}\end{array}$ & $\begin{array}{l}-11.218 \\
{[-0.946]}\end{array}$ & $\begin{array}{l}155.721^{\mathrm{a}} \\
{[11.183]^{\mathrm{b}}}\end{array}$ \\
\hline Year -1 & $\begin{array}{l}19.600 \\
{[1.313]}\end{array}$ & $\begin{array}{l}229.854 \\
{[19.625]}\end{array}$ & $\begin{array}{l}30.389 \\
{[1.122]}\end{array}$ & $\begin{array}{l}70.307 \\
{[8.000]}\end{array}$ & $\begin{array}{r}-10.789 \\
{[0.191]}\end{array}$ & $\begin{array}{l}159.547^{\mathrm{b}} \\
{[11.625]^{\mathrm{c}}}\end{array}$ \\
\hline Year +1 & $\begin{array}{l}28.579 \\
{[1.819]}\end{array}$ & $\begin{array}{l}299.976 \\
{[50.630]}\end{array}$ & $\begin{array}{l}21.527 \\
{[0.716]}\end{array}$ & $\begin{array}{l}95.895 \\
{[8.121]}\end{array}$ & $\begin{array}{c}7.052^{\mathrm{c}} \\
{[1.103]^{\mathrm{c}}}\end{array}$ & $\begin{array}{l}204.081^{\mathrm{a}} \\
{[42.509]^{\mathrm{a}}}\end{array}$ \\
\hline Year +2 & $\begin{array}{l}31.255 \\
{[1.282]}\end{array}$ & $\begin{array}{l}379.617 \\
{[53.565]}\end{array}$ & $\begin{array}{l}24.311 \\
{[0.585]}\end{array}$ & $\begin{array}{r}132.344 \\
{[3.213]}\end{array}$ & $\begin{array}{c}6.944^{\mathrm{c}} \\
{[0.697]^{\mathrm{c}}}\end{array}$ & $\begin{array}{l}247.273^{\mathrm{a}} \\
{[50.352]^{\mathrm{a}}}\end{array}$ \\
\hline Year +3 & $\begin{array}{l}34.476 \\
{[2.150]}\end{array}$ & $\begin{array}{l}425.125 \\
{[38.950]}\end{array}$ & $\begin{array}{l}25.999 \\
{[0.810]}\end{array}$ & $\begin{array}{l}158.742 \\
{[12.050]}\end{array}$ & $\begin{array}{c}8.477^{\mathrm{a}} \\
{[1.340]^{\mathrm{a}}}\end{array}$ & $\begin{array}{l}266.383^{\mathrm{a}} \\
{[26.90]^{\mathrm{b}}}\end{array}$ \\
\hline Year after - Year before & $\begin{array}{c}8.979 \\
{[0.506]}\end{array}$ & $\begin{array}{c}70.122^{\mathrm{c}} \\
{[31.005]^{\mathrm{c}}}\end{array}$ & & & & \\
\hline $\begin{array}{l}{[\text { Years }+1 \text { and }+2]-} \\
{[\text { Years }-1 \text { and }-2]}\end{array}$ & $\begin{array}{l}25.586^{\mathrm{b}} \\
{[5.657]^{\mathrm{b}}}\end{array}$ & $\begin{array}{l}236.137^{\mathrm{c}} \\
{[49.124]^{\mathrm{c}}}\end{array}$ & & & & \\
\hline $\begin{array}{l}{[\text { Years }+1,+2 \text {, and }+3]-} \\
{[\text { Years }-1,-2 \text {, and }-3]}\end{array}$ & $\begin{array}{l}47.232^{\mathrm{c}} \\
{[2.597]^{\mathrm{c}}}\end{array}$ & $\begin{array}{l}456.642^{\mathrm{c}} \\
{[64.373]}\end{array}$ & & & & \\
\hline
\end{tabular}

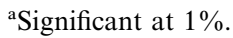

${ }^{\mathrm{b}}$ Significant at $5 \%$.

${ }^{\mathrm{c}}$ Significant at $10 \%$.

the first two years following spin-offs, however, the firms that engage in spin-offs issue equity more frequently than the control firms. These differences are statistically significant (using the proportions test) at the $10 \%$ level. We find that among firms that engage in spin-offs the frequency of equity issuance increases following a spin-off. For the sample firms, in the two years after a spin-off, we find a total of 30 equity issues, compared to only 20 in the two years before the spin-off. This difference is significant at the $10 \%$ level.

In Panel B of Table 9 we report the dollar amounts of equity and debt raised by the sample and control firms. Firms that divest through spin-offs raise more capital following spin-offs than their size- and industry-matched control firms. For instance, in the second year following the spin-off, firms that engage in spin-offs raise on average about $\$ 7$ million more in equity and about $\$ 247$ 
million more in debt than control firms. These differences are statistically significant at least at the $10 \%$ level. Perhaps more importantly, firms that engage in spin-offs raise more capital following a spin-off than before. In the two years after a spin-off, the mean equity (debt) raised is about $\$ 25$ million ( $\$ 236$ million) higher than the mean equity (debt) raised in the two years before the spin-off. The difference in equity (debt) amounts is significant at the $5 \%$ $(10 \%)$ level of significance. These results suggest that firms that engage in spin-offs raise more external capital following the spin-offs. Moreover, in each of the three years before a spin-off we find that sample firms issue significantly more debt than their size- and industry-matched counterparts. Thus the evidence is consistent with the view that firms that engage in spin-offs find external equity to be costly before a spin-off, perhaps due to information problems (Nanda and Narayanan, 1997). Following a spin-off, however, the firms have reduced information problems and an improved share price and issue more equity.

\subsection{Information asymmetry and the likelihood of a spin-off}

In this section, we use the information asymmetry variables and the unrelated entropy variable in conditional logistic regressions to explain the incidence of spin-offs. The dependent variable in these regressions is an indicator variable that is 1 for firms that divest through a spin-off and 0 for the control firms. The information hypothesis argues that the likelihood of a spin-off is increasing in the level of information asymmetry, and the elimination of negative synergies hypothesis argues that the likelihood is increasing in the level of negative synergies across the divisions of a firm. Furthermore, information asymmetry plays an important role in firms that are liquidity-constrained and thus forced to depend on external capital (Nanda and Narayanan, 1997). A hypothesis that emerges from this argument is that high-growth firms and those with low levels of internally generated cash have a higher likelihood of engaging in a spin-off. Following Smith and Watts (1992), for each firm we use the ratio of the market value of its assets to the book value of its assets as a proxy for the growth options in the firm's investment opportunity set. Market value is estimated as the book value of assets minus the book value of equity plus the market value of equity.

The conditional logistic regression 1 in Table 10 indicates that forecast errors are significantly positively associated with the incidence of spin-offs, which is consistent with the information hypothesis. The coefficient of forecast errors is 32.955 , and it has a $p$-value of 0.015 . The coefficient of the unrelated entropy variable is positive and significant ( $p$-value 0.013 ), indicating that the higher the level of unrelated diversification in operations by a firm the higher the likelihood that it will divest some of its divisions through a spin-off. Cash flow from operations, which is a measure of liquidity, has a significantly negative 
coefficient, suggesting that low levels of internally generated cash lead to a higher incidence of spin-offs. To control for the growth opportunities available to the firm, we use a high-growth indicator variable, which is set to 1 if the market-to-book ratio of the firm is higher than the median market-to-book ratio of the set of all sample and control firms and 0 otherwise. The significantly positive coefficient of this variable suggests that high-growth firms show a higher incidence of spin-offs. These results are consistent with the implications of the Nanda and Narayanan (1997) argument that spin-offs are a precursor to raising capital.

Regressions 2 through 5 use the other four measures of information asymmetry, while retaining the unrelated entropy, growth, and corporate liquidity variables from regression 1. Consistent with the information hypothesis, the coefficient of the information asymmetry variables are positive and significant in all regressions. The unrelated entropy variable also has a positive coefficient that is significant at least at the $5 \%$ level in all the regressions.

Finally, the coefficients of the growth and the liquidity variables are significant and have the expected signs. The coefficient of the high-growth dummy variable is significantly positive at the $5 \%$ level in all the regressions, while the coefficient of the cash flow from operations variable is significantly negative in each regression. This suggests that high-growth firms and firms with low levels of internally generated cash divest divisions through spin-offs, even though spin-offs themselves generate no new capital for the firms. The result is consistent with the view that firms engage in spin-offs to mitigate information asymmetry in the capital markets before approaching the market for funds. The results are robust to alternative proxies for the internal cash flow generated by a firm. In regressions 6 through 10 we replace the cash flow from operations variable with the firm's operating income. This variable is the firm's sales minus costs of goods sold and other expenses, before depreciation and amortization, and is measured relative to the total assets of the firm. All our results remain unchanged even with this proxy.

Since the logistic regressions suggest that investors in the market may be able to predict the incidence of spin-offs, a spin-off may be partially anticipated by the market and the associated wealth effects may be impounded in the stock price even before the firm announces the spin-off. The returns we observe upon the announcement of a spin-off may therefore underestimate the total wealth effect of a spin-off. Following the methodology in Eckbo et al. (1990) and Bhagat and Jefferis (1991), we compute the anticipation-adjusted abnormal returns using the predicted probabilities generated by a logistic regression.

We compute the anticipation-adjusted wealth effect of a spin-off as follows. Let $P_{\mathrm{NS}}$ be the stock price of a firm if it does not engage in a spin-off, and let $P_{\mathrm{S}}$ be the stock price of the firm if it engages in a spin-off. Let $0 \leqslant \pi<1$ be the market's assessment of the probability that the firm will engage in a spin-off. If there is partial anticipation of the spin-off in the market, the stock price of the 


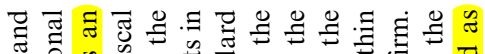

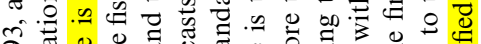

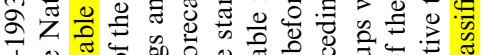

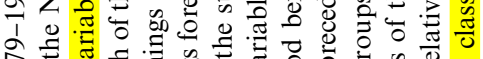

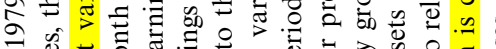

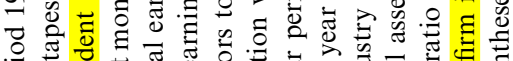

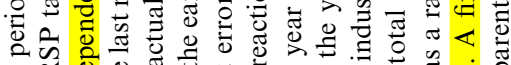

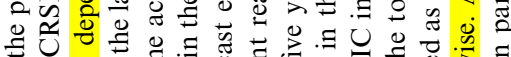

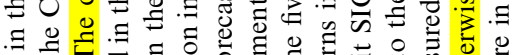
\&

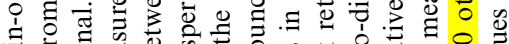

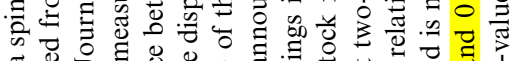

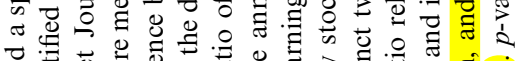

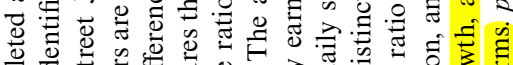

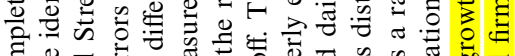

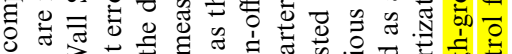

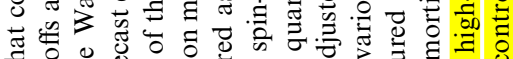
त्ञ

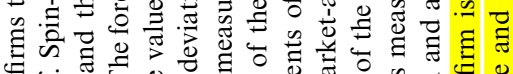

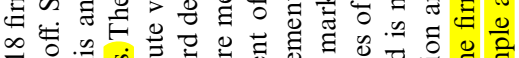

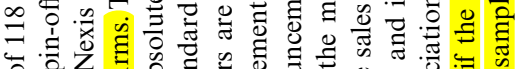

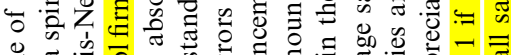

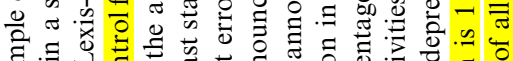

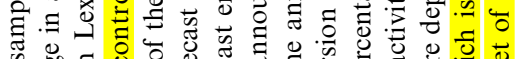
焉品

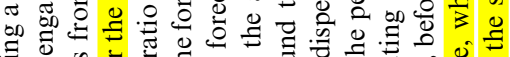

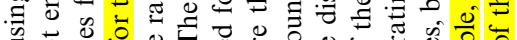

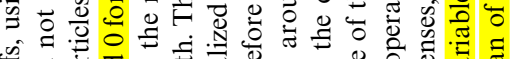

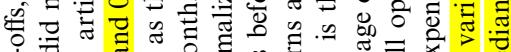

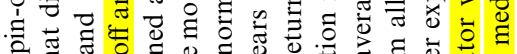
क人

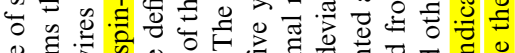

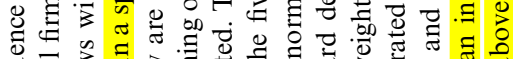

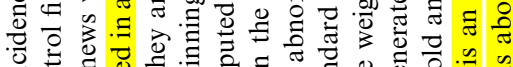

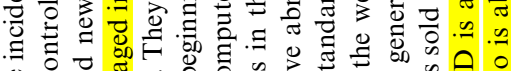
势

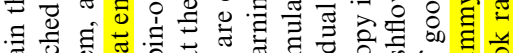

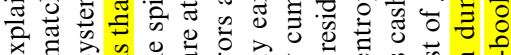

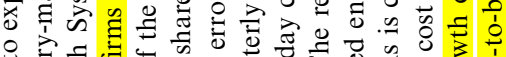
으의

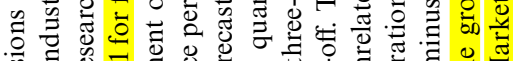

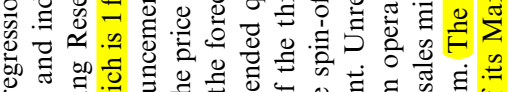

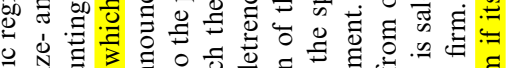

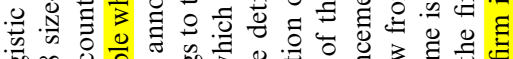

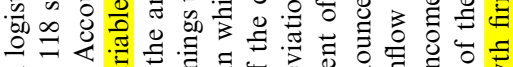
चु

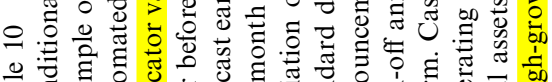

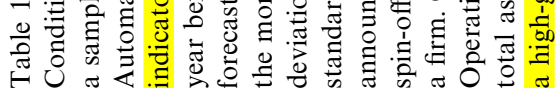

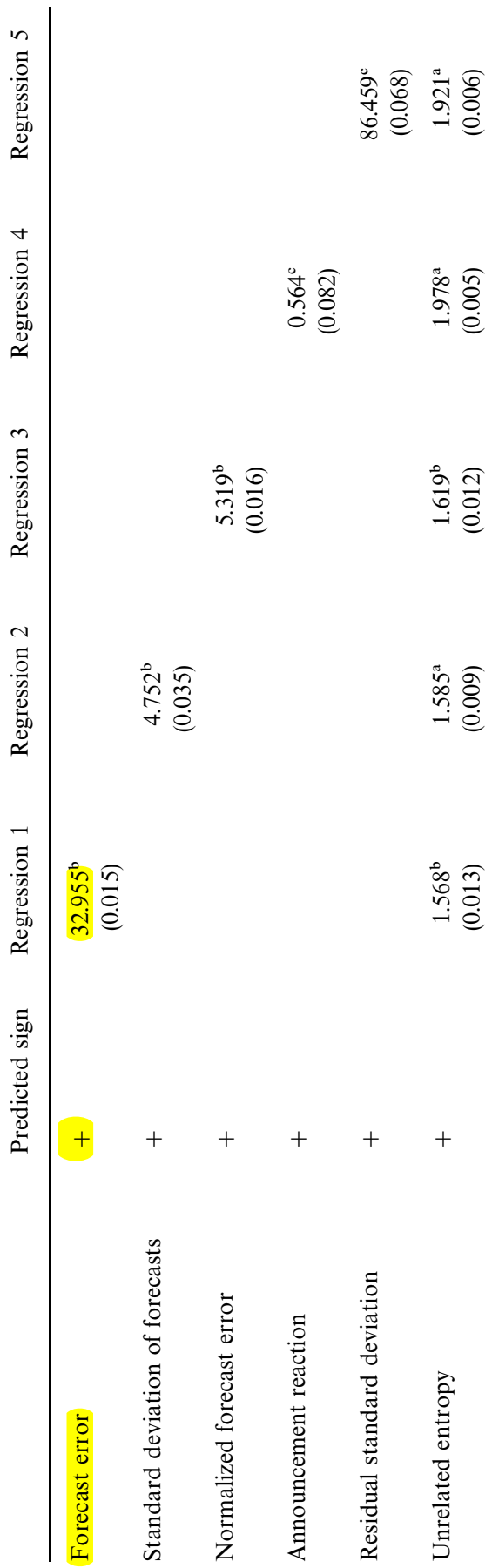




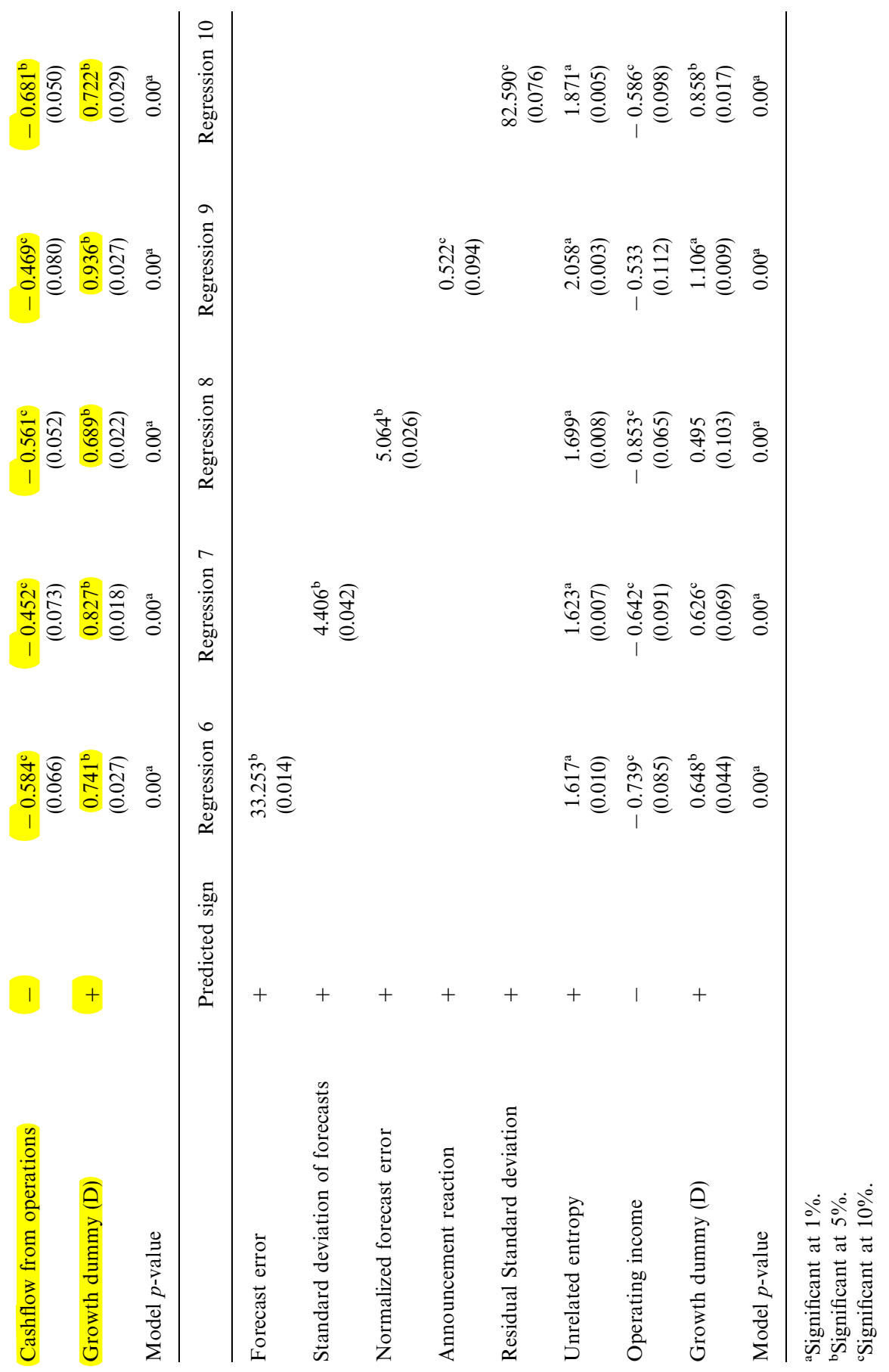


firm before the spin-off announcement would be $P$, where $P=\pi P_{\mathrm{S}}+$ $(1-\pi) P_{\text {NS. }}$. Hence, upon the announcement of a spin-off, the observed return on the firm's stock is $r_{\mathrm{O}}=\left(P_{\mathrm{S}}-P\right) / P$. However, the true (anticipation-adjusted) wealth effect of a spin-off is $r_{\mathrm{T}}=\left(P_{\mathrm{S}}-P_{\mathrm{NS}}\right) / P_{\mathrm{NS}}$. Now, using $P=\pi P_{\mathrm{S}}+$ $(1-\pi) P_{\mathrm{NS}}$, the anticipation-adjusted wealth effect $r_{\mathrm{T}}$ of a spin-off can be rewritten as $r_{\mathrm{T}}=r_{\mathrm{O}} /\left((1-\pi)-\pi r_{\mathrm{O}}\right)$, where $0 \leqslant \pi<1$ (see Bhagat and Jefferis, 1991). For each firm, $r_{\mathrm{O}}$ is observed at the spin-off announcement and $\pi$ is estimated using a logistic regression with the variables in model (1) of Table 10. The mean two-day anticipation-adjusted abnormal return in the interval $(-1,0)$ for our sample of spin-offs is $3.71 \%$ which is about $18 \%$ higher than the corresponding unadjusted abnormal return of $3.15 \%$ reported in Table 4 .

\subsection{Sources of gains in spin-offs}

In this section, we confirm our univariate results that relate information asymmetry and abnormal returns around spin-offs using regression analysis. We use the two-day anticipation-adjusted abnormal returns in the interval $(-1,0)$ as the dependent variable in the regressions in Tables 11 and 12. We use all five measures of information asymmetry in the regressions to test the information hypothesis. The information hypothesis predicts a positive relation between the measures of information asymmetry and the anticipation-adjusted abnormal returns. To examine the predictions of the negative synergies hypothesis we use the cross-industry dummy variable, which is 1 for cross-industry spin-offs and 0 for same-industry spin-offs. We expect to see a positive relation between this variable and the anticipation-adjusted abnormal returns. We also use the unrelated entropy index as an alternative measure of negative synergies within a firm. Since unrelated entropy is high for diversified firms, we expect a positive relation between unrelated entropy and abnormal returns if the spin-off gains are driven by the elimination of negative synergies.

Other factors in the regressions control for the other theories that have been proposed in the literature. Hite and Owers (1983) and Miles and Rosenfeld (1983) find that the announcement period gains are larger when a firm divests a larger portion of its assets. We use the market value of equity of the divested subsidiary measured relative to the sum of the equity capitalizations of the parent and the subsidiary (computed in the month of the completion of the spin-off) to control for size related effects. An indicator variable distinguishes sample firms that have stated a merger motive. This merger dummy is set to 1 if the firm stated that the spin-off was undertaken to facilitate a merger and is set to 0 otherwise. We expect the coefficient of this merger dummy to be positive. A regulation dummy variable distinguishes firms with a regulation motive. For each sample firm, the regulation dummy is set to 1 if either the firm or the subsidiary, but not both, is in an unregulated industry and is set to 0 otherwise. If dissociation of an unregulated division from a regulated division provides 
gains to the shareholders, we expect the coefficient of the regulation dummy to be significant and positive. Finally, to account for the tax status of a spin-off, we use a tax dummy, which is 1 if the spin-off has been ruled as taxable and 0 otherwise. The coefficient of the tax dummy is expected to be negative since taxation imposes a penalty on shareholders' gains.

Table 11 reports the parameter estimates in the different regressions and their heteroskedasticity adjusted $t$-statistics. All the variables in regression 1 show the expected signs. The coefficient of the forecast error variable is 14.239 and significant at the $1 \%$ level, confirming the positive relation between abnormal returns and information asymmetry. We also compute the economic impact of the variables. We measure the economic impact of an independent variable as the change in wealth gains from a spin-off (as a fraction of the mean wealth gain) when we increase the variable by one standard deviation. The coefficient of forecast error in regression 1 implies that when we increase forecast error by one standard deviation the anticipation-adjusted abnormal returns increase by 147 basis points. This increase represents a large fraction $(39.6 \%)$ of the mean wealth gain around spin-offs.

Consistent with the elimination of negative synergies hypothesis, the coefficient of the cross-industry SIC dummy is 1.459 , which is significant at the $10 \%$ level. The economic impact of this variable is large. From regression 1, a firm that divests an unrelated division earns 146 basis points more than a firm that divests a related division. This represents a 39\% increase in anticipationadjusted abnormal returns. The relative size of the divested unit is also significantly positively related to the gains around spin-off announcements, which is similar to the finding in Miles and Rosenfeld (1983). The economic impact of this variable computed using the coefficient in regression 1 is nearly $32 \%$. The only other significant factor is the tax dummy, which is negative, suggesting that taxable spin-offs have lower abnormal returns than nontaxable spin-offs. In particular, from regression 1 we may infer that in taxable spin-offs shareholders earn about 200 basis points less than in nontaxable spin-offs. The coefficient of the merger motive dummy is positive but not statistically different from zero. Finally, the coefficient of the regulation dummy is not significant, which suggests that the abnormal returns are not related to the elimination of regulatory constraints.

Regressions 2 through 5 repeat the analysis of regression 1 using the different information asymmetry variables successively. Consistent with the information hypothesis, all the information asymmetry variables but residual standard deviation are significantly positively related to the abnormal returns. For instance, the coefficient of the normalized forecast error variable in regression 3 is 9.700 , and it is significant at the $1 \%$ level. The economic impact of this variable is very large. When normalized forecast error increases by one standard deviation, anticipation-adjusted abnormal returns increase by 347 basis points. The residual standard deviation variable in regression 5 shows the weakest 


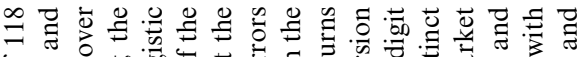

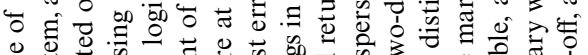

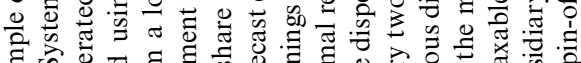

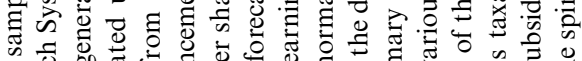

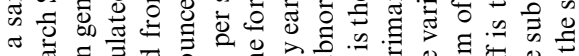

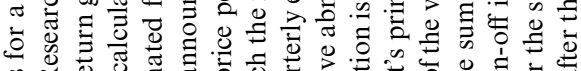

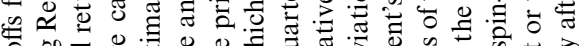

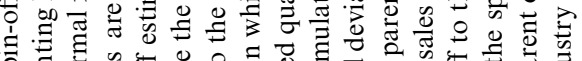

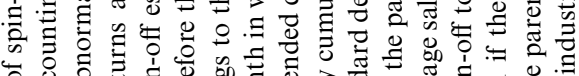

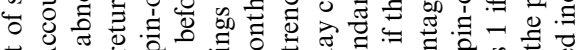

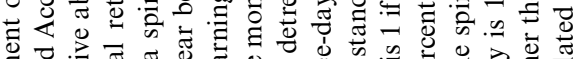

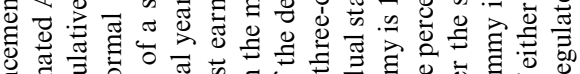

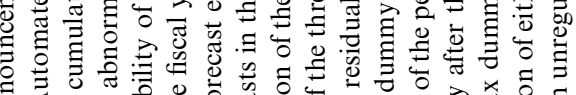

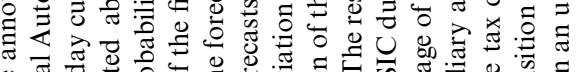

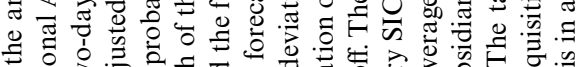

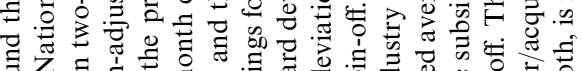

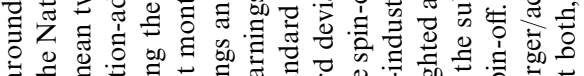

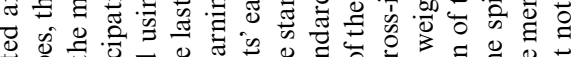

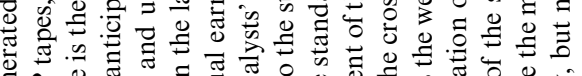

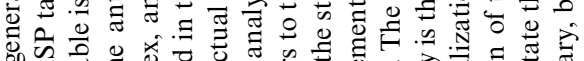

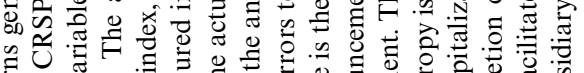

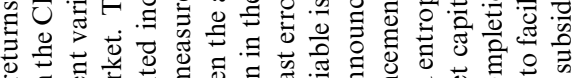

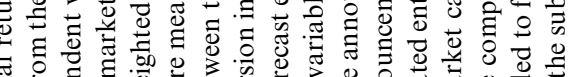

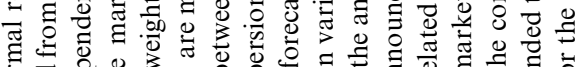

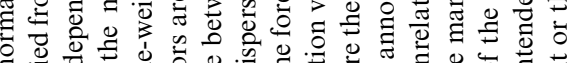

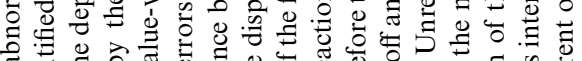

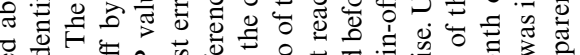
च

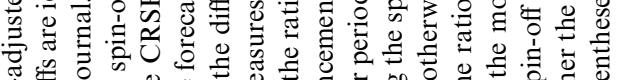

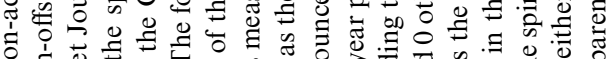
.ี.

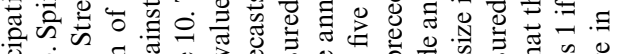
可

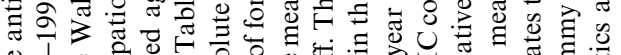

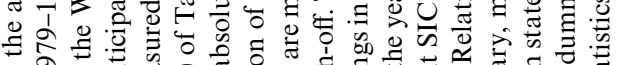

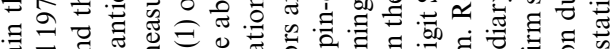

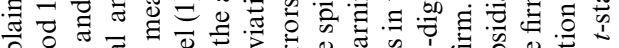

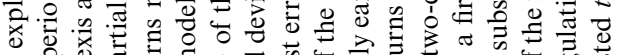

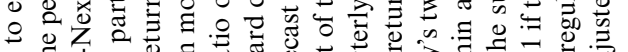

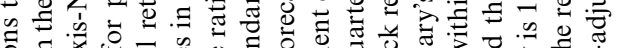
.0.

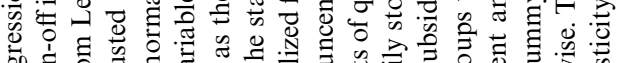

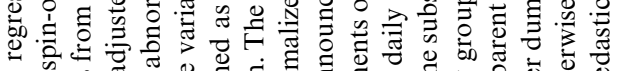
क क ఫ్ర

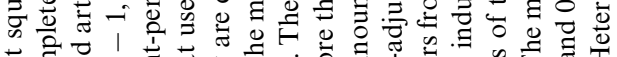

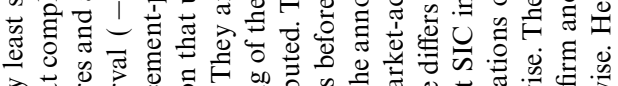

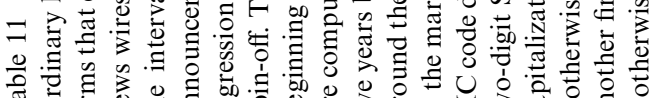

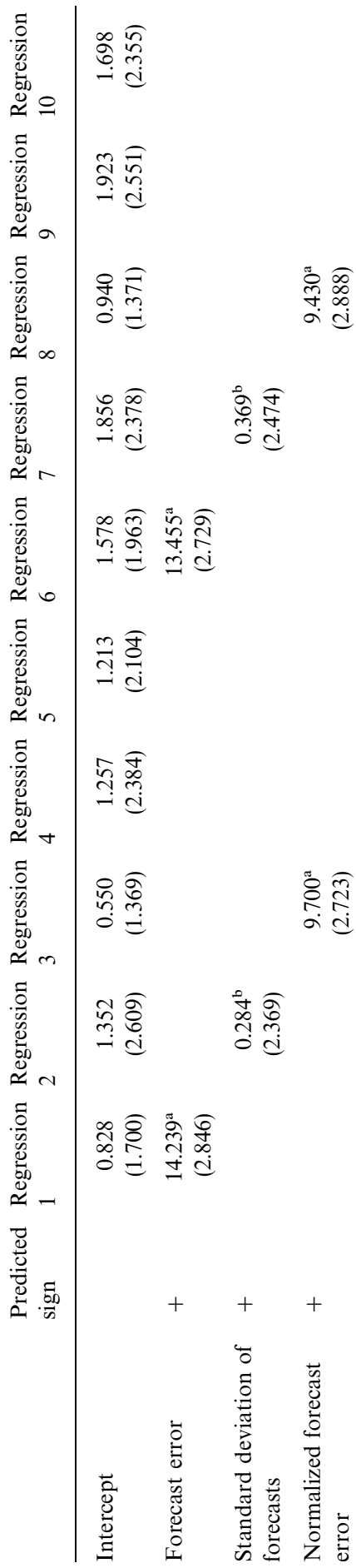


锌重

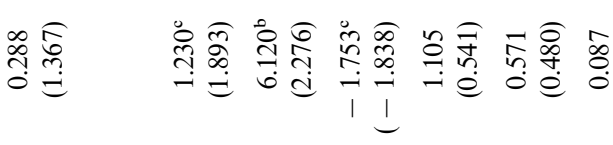

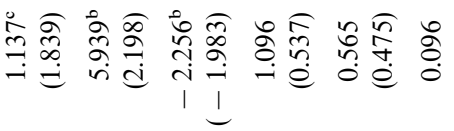

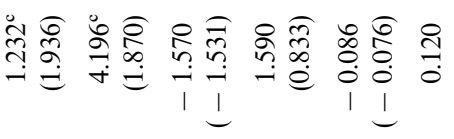

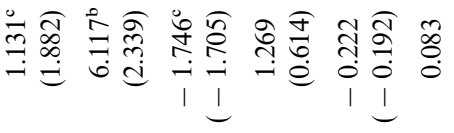

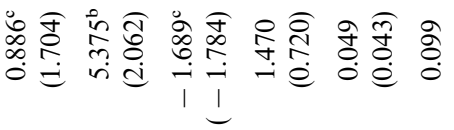

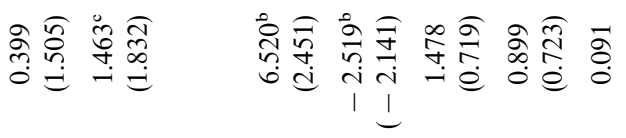

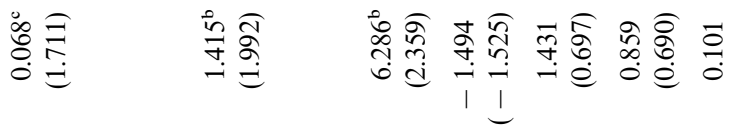

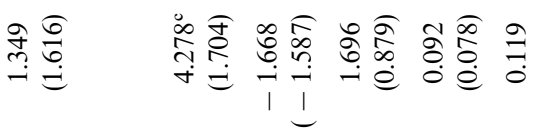

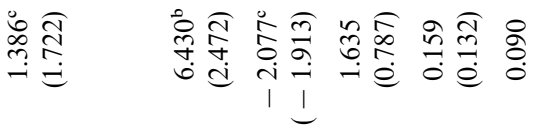

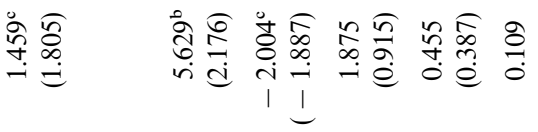

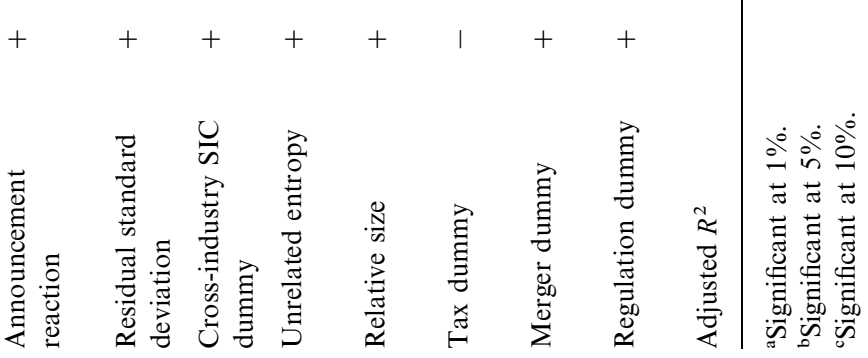




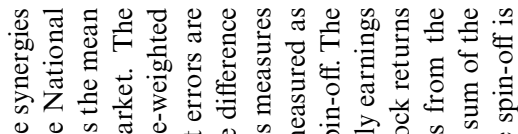

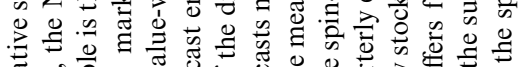

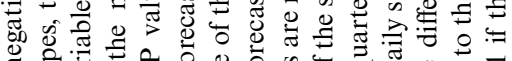

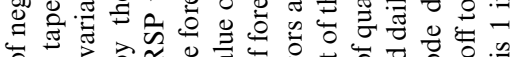

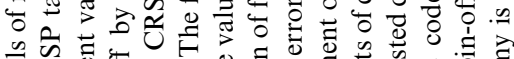

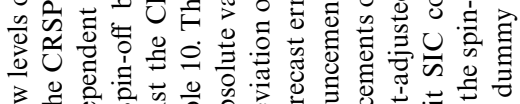

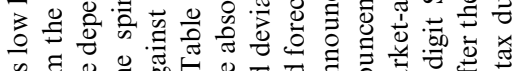

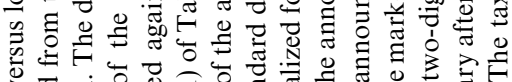

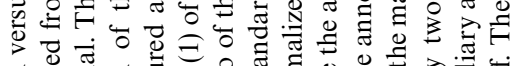

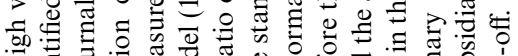

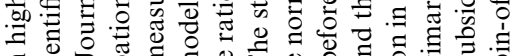

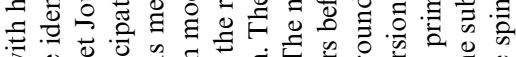

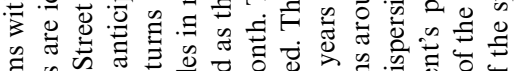

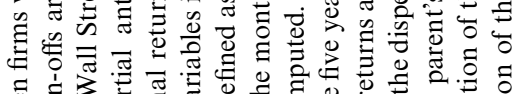

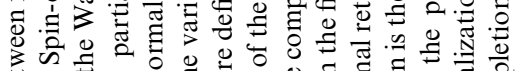

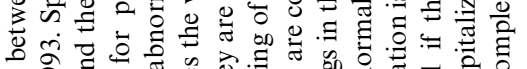
क人े

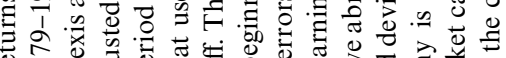

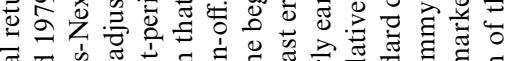

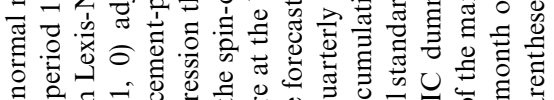

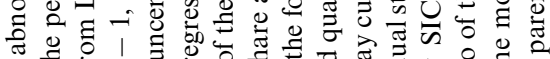
元导

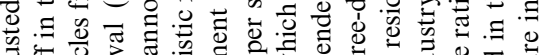

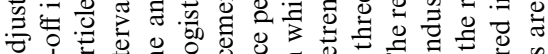

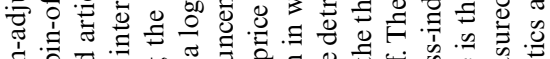

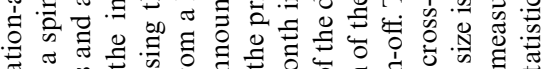

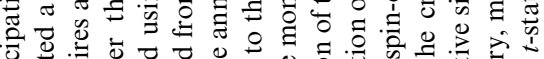

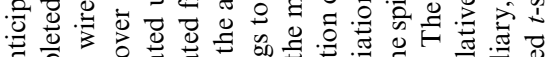

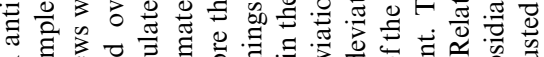
ठี

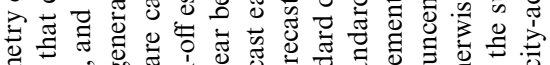

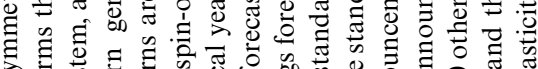

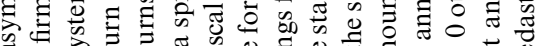

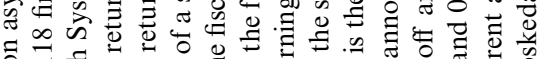
‡: .

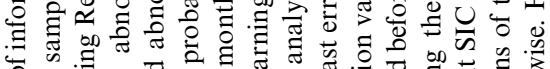

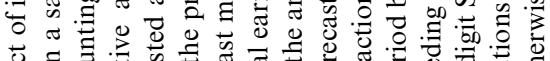

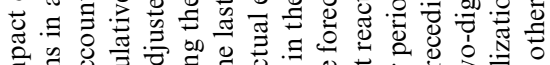

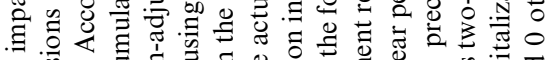

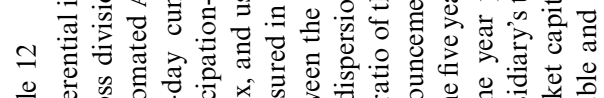

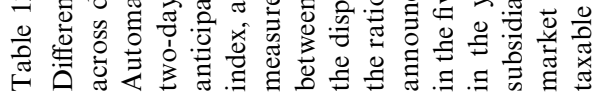

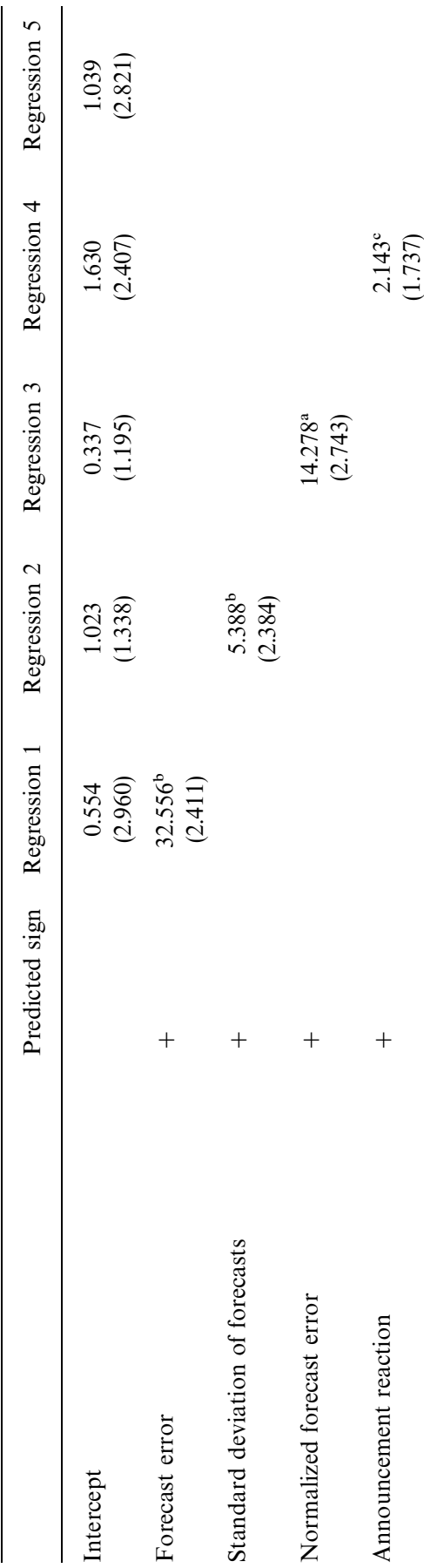


学导

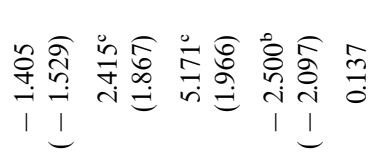

華旅

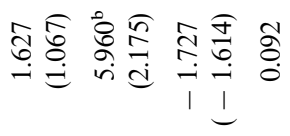

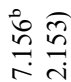

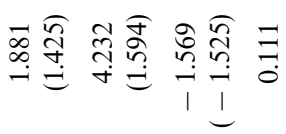

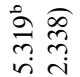

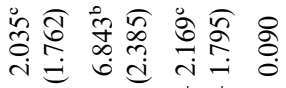

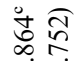

กิ่

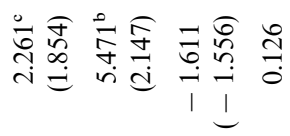

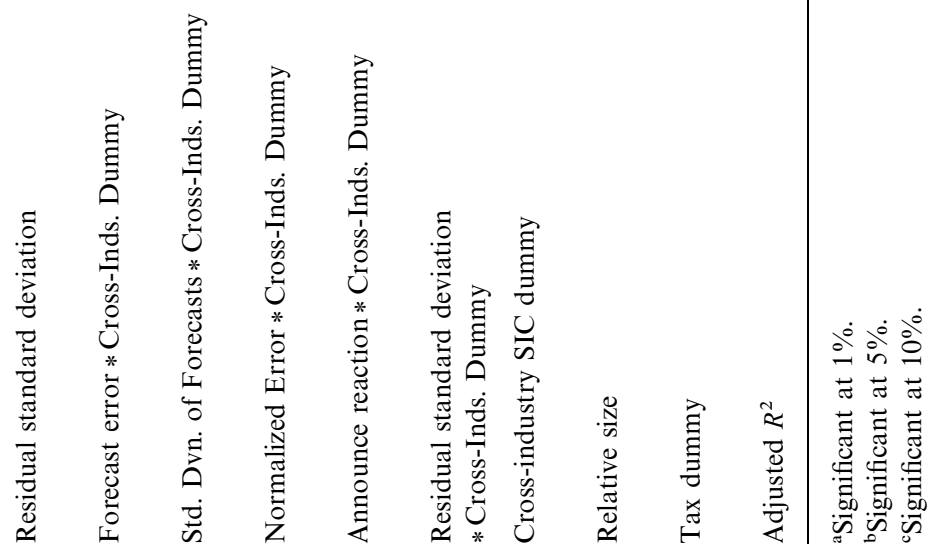


relation with announcement period abnormal returns among the information asymmetry variables. The coefficient of this variable, though positive, is not significant at the conventional levels of significance. The economic impact of this variable is only $6.5 \%$. The regression results also offer some support for the elimination of negative synergies hypothesis. We find that the coefficient of the cross-industry SIC dummy is positive and significant in all but one regression. As before, compared to same-industry spin-offs, the crossindustry spin-offs earn 135 to 146 basis points more in anticipation-adjusted abnormal returns. The merger-motive dummy and the regulation dummy are not significant in any of the regressions, while the relative size of the spun-off subsidiary is significantly positively related to the abnormal returns in all the regressions.

Regressions 6 through 10 repeat the analysis in regressions 1 to 5 with the cross-industry dummy variable replaced by the unrelated entropy variable. As before, the information asymmetry variables are significantly positively related to the abnormal returns, with the exception of regression 10 . The economic impact of the variables inferred from these coefficients are similar to those from regressions 1 through 5 . The regression results offer some support for the elimination of negative synergies hypothesis. Unrelated entropy is significantly positively related to the anticipation-adjusted abnormal returns in all the five regressions. The economic impact of this variable ranges from $11 \%$ to $15 \%$ across the regressions. The coefficients of the other variables are similar in magnitude and significance to their counterparts in the previous regressions.

Following the approach in Chan and Lakonishok (1992) and Bhagat and Welch (1995), we re-estimate the coefficients in the regressions in Table 11 using the Koenker and Bassett (1978) robust regression technique. We find that our main inferences are, in general, unaffected, but the coefficients of two of our measures of information asymmetry (announcement reaction and residual standard deviation) are not statistically significant in the robust regressions. The coefficients of the firm-diversification measures (cross-industry SIC dummy and unrelated entropy) are not significant in one regression. These results are available from the authors upon request.

In the regressions in Table 12, we examine whether there is a difference in the impact of information asymmetry on abnormal returns between firms that have the alternative motive of eliminating negative synergies and those that do not have such a motive. To the extent that same-industry spin-offs have few negative synergies (or even some positive synergies), the cost imposed by information asymmetry must be sufficiently high to motivate a spin-off. We therefore expect the impact of information asymmetry on abnormal returns to be greater for the same-industry spin-offs than for the cross-industry spin-offs. To examine whether there is such a differential impact we introduce an interaction term in the regressions in Table 12 while leaving out all the insignificant variables from 
the previous regressions. The interaction of the information asymmetry variable with the cross-industry dummy measures the incremental impact of information asymmetry on abnormal returns for the subsample of cross-industry spin-offs over the same-industry spin-offs. The main variable of information asymmetry in this regression then measures the impact of information asymmetry on abnormal returns in the same-industry subsample. The expected sign of the main information asymmetry variable is positive, while that of the interaction term is negative.

The regression results in Table 12 indicate that information asymmetry is significantly positively related to the anticipation-adjusted returns, while the interaction term is negative and significant in all but regression 5. Furthermore, the magnitude of the interaction term is smaller than the magnitude of the information asymmetry term, confirming that, while the effect of information asymmetry on the abnormal returns is positive for the sameindustry subsample, it is positive but smaller for the cross-industry subsample. For instance, the coefficient of the forecast error variable in regression 1 of Table 12 is 32.556, which is significantly different from zero at the $5 \%$ level. The interaction coefficient is -22.864 , which is significant at the $10 \%$ level. These results imply that in the same-industry spin-off subsample the coefficient of forecast error is 32.556 , while it is $9.692(=32.556-22.864)$ in the crossindustry subsample. The significant interaction coefficient suggests that there is a significant difference in the impact of forecast error on abnormal returns between the cross-industry and same-industry spin-offs. Regression 1 implies that an increase of one standard deviation in forecast error in the same-industry subsample increases the anticipation-adjusted abnormal returns by 391 basis points. A corresponding increase in forecast error in the crossindustry subsample results in only a 95 basis point increase in the abnormal returns.

From regression 4, the coefficient of the announcement reaction variable is 2.143 for the same-industry spin-offs, which is significant at the $10 \%$ level. The interaction coefficient of -2.097 , which is significant at the $5 \%$ level, implies that the differential impact of the announcement reaction variable on abnormal returns between the cross-industry and sameindustry spin-offs is significant. These coefficients suggest that an increase of one standard deviation in the announcement reaction variable in the same-industry spin-offs increases the anticipation-adjusted abnormal returns by 46 basis points, while a corresponding increase in the cross-industry spin-offs results in an increase of only 11 basis points. Residual standard deviation is the only measure of information asymmetry that does not exhibit a differential impact on abnormal returns between the cross and same-industry subsamples. The coefficients and the economic impact of the other variables are qualitatively similar to the corresponding regressions in Table 11. 


\section{Conclusion}

This study analyzes the role of information asymmetry in explaining the incidence of and gains associated with corporate spin-offs. The information hypothesis argues that spin-offs reduce information asymmetry in the market about the cash flows and operating efficiency of the individual divisions of a firm. Firms that are undervalued due to information asymmetry therefore experience an improvement in market valuation when they divest through spin-offs. Using five different measures of information asymmetry, including analysts' earnings forecast errors and the standard deviation of the earnings forecasts, we empirically examine the premise and the implications of the information hypothesis.

We find that firms that engage in spin-offs have higher levels of information asymmetry before the spin-off than their size- and industry-matched counterparts. We also find that for the sample firms information problems decrease significantly after the completion of the spin-off. The anticipation-adjusted abnormal returns around the announcement of spin-offs are larger for firms with higher levels of information asymmetry. This result obtains even after controlling for the level of negative synergies between divisions of a firm.

Furthermore, for firms that spin off related subsidiaries (i.e., firms with fewer negative synergies between divisions) information problems are a more important determinant of the anticipation-adjusted abnormal returns. Thus, while negative synergies may play a role in explaining spin-off gains, mitigation of information asymmetry is also an important factor. We do not find any evidence to support the regulation and the merger motives for spin-offs. In particular, spin-offs that potentially eliminate regulatory constraints for either the parent or the subsidiary and those undertaken to facilitate a merger do not exhibit higher announcement period abnormal returns.

Logistic regressions indicate that firms with higher levels of information asymmetry and firms that are highly diversified have a higher likelihood of engaging in spin-offs. We also find that firms with higher growth opportunities and those that are liquidity-constrained (i.e., firms that have a need for external capital) show a higher propensity to engage in spin-offs, even though spin-offs themselves generate no new capital for the firms. Among firms that engage in spin-offs, both the frequency of equity issues and the total amount of capital raised increase significantly in the two years following a spin-off. This is consistent with the view that firms improve their market value through divestitures that reduce information asymmetry before approaching the capital market for funds.

\section{References}

Allen, J., Lummer, S., McConnell, J., Reed, D., 1995. Can takeover losses explain spin-off gains? Journal of Financial and Quantitative Analysis 30, 465-485. 
Aron, D., 1991. Using the capital market as a monitor: corporate spin-offs in an agency framework. RAND Journal of Economics 22, 505-518.

Baker, S., 1996. Who's really out from under at Westinghouse? Business Week, November 25, 1996, p. 38.

Berger, P., Ofek, E., 1995. Diversification's effect on firm value. Journal of Financial Economics 37, 39-65.

Bhagat, S., Jefferis, R., 1991. Voting power in the proxy process: the case of antitakeover charter amendments. Journal of Financial Economics 30, 193-225.

Bhagat, S., Marr, W., Thompson, R., 1985. The Rule 415 experiment: equity markets. Journal of Finance 40, 1385-1401.

Bhagat, S., Welch, I., 1995. Corporate research and development investments: international comparisons. Journal of Accounting and Economics 19, 443-470.

Blackwell, D., Marr, W., Spivey, M., 1990. Shelf registration and the reduced due diligence argument: Implications of the underwriter certification and the implicit insurance hypotheses. Journal of Financial and Quantitative Analysis 25, 245-259.

Carton, B., 1995. Raytheon considering a partial spin-off of its fast-growing engineering unit. Wall Street Journal, March 6, p. A4.

Chan, L., Lakonishok, J., 1992. Robust measurement of beta risk. Journal of Financial and Quantitative Analysis 27, 265-282.

Christie, A., 1987. On cross-sectional analysis in accounting research. Journal of Accounting and Economics 9, 231-258.

Comment, R., Jarrell, G., 1995. Corporate focus and stock returns. Journal of Financial Economics $37,67-87$.

Cusatis, P., Miles, J., Woolridge, J., 1993. Restructuring through spin-offs: the stock market evidence. Journal of Financial Economics 33, 293-311.

Daley, L., Mehrotra, V., Sivakumar, R., 1997. Corporate focus and value creation: evidence from spin-offs. Journal of Financial Economics 45, 257-281.

Desai, H., Jain, P., 1999. Firm performance and focus: long-run stock market performance following spin-offs. Journal of Financial Economics, forthcoming.

Dierkens, N., 1991. Information asymmetry and equity issues. Journal of Financial and Quantitative Analysis 26, 181-199.

Dodd, P., Warner, J., 1983. On corporate governance: a study of proxy contests. Journal of Financial Economics 27, 401-438.

Eckbo, E., Maksimovic, V., Williams, J., 1990. Consistent estimation of cross-sectional models in event studies. Review of Financial Studies 3, 343-365.

Elton, E., Gruber, M., Gultekin, M., 1984. Professional expectations: accuracy and diagnosis of errors. Journal of Financial and Quantitative Analysis 19, 351-363.

Emmanuel, C., Mehafdi, M., 1994. Transfer Pricing. Academic Press, New York.

Fried, D., Givoly, D., 1982. Financial analysts' forecasts of earnings: a better surrogate for market expectations. Journal of Accounting and Economics 4, 85-107.

Gilson, S., Healy, P., Noe, C., Palepu, K., 1998. Corporate focus and the benefits from more specialized analyst coverage. Unpublished working paper. Harvard University, Cambridge.

Hite, G., Owers, J., 1983. Security price reactions around corporate spin-off announcements. Journal of Financial Economics 12, 409-436.

Hoskisson, R., Hitt, M., 1994. Downscoping. Oxford University Press, New York.

Hwang, S., 1995. RJR may be looking to spin off the rest of Nabisco. Wall Street Journal, March 17, p. B4.

John, K., Ofek, E., 1995. Asset sales and increase in focus. Journal of Financial Economics 37, 105-126.

Keller, J., 1995. Divide to conquer: AT\&T to split into three. Wall Street Journal, September 21, p. A8. 
Koenker, R., Bassett, G., 1978. Regression quantiles. Econometrica 46, 33-50.

Krishnaswami, S., Spindt, P., Subramaniam, V., 1999. Information asymmetry, monitoring, and the placement structure of corporate debt. Journal of Financial Economics 51, 407-434.

Miles, J., Rosenfeld, J., 1983. The effect of voluntary spin-off announcements on shareholder wealth. Journal of Finance 38, 1597-1606.

Miller, E., 1995. Why the break-up of conglomerate business enterprises often increases value. Journal of Social, Political, and Economic Studies 20, 317-341.

Nanda, V., Narayanan, M., 1997. Disentangling value: misvaluation and the scope of the firm. Unpublished working paper, University of Michigan, Ann Arbor.

O'Brien, P., 1988. Analysts' forecasts and earnings expectations. Journal of Accounting and Economics 10, 53-83.

Palepu, K., 1985. Diversification strategy, profit performance and the entropy measure. Strategic Management Journal 6, 239-255.

Parrino, R., 1997. Spin-offs and wealth transfers: the Marriott case. Journal of Financial Economics 43, 241-274.

Rosenfeld, J., 1984. Additional evidence on the relation between divestiture announcements and shareholder wealth. Journal of Finance 39, 1437-1448.

Schipper, K., Smith, A., 1983. Effects of recontracting on shareholder wealth: the case of voluntary spin-offs. Journal of Financial Economics 12, 437-467.

Seward, J., Walsh, J., 1996. The governance and control of voluntary corporate spin-offs. Strategic Management Journal 17, 25-40.

Smith, C., Watts, R., 1992. The investment opportunity set and corporate financing, dividend, and compensation policies. Journal of Financial Economics 32, 263-292.

Vijh, A., 1994. The spin-off and merger ex-date effects. Journal of Finance 49, 581-609. 